\title{
An Ecological Approach to Riparian-Buffer Definition, and Implications for Timber Harvests in Nova Scotia, Canada
}

\author{
Patricia Stoffyn-Egli ${ }^{1} \&$ Peter N. Duinker ${ }^{1}$ \\ ${ }^{1}$ School for Resource and Environmental Studies, Dalhousie University, Halifax, Nova Scotia, Canada \\ Correspondence: Patricia Stoffyn-Egli, School for Resource and Environmental Studies, Dalhousie University, \\ 6100 University Avenue, Halifax, Nova Scotia, B3H 4R2, Canada. Tel: 1-902-494-3632. E-mail: \\ pstoffyn@dal.ca
}

Received: June 6, 2013 Accepted: November 19, 2013 Online Published: November 27, 2013

doi:10.5539/jsd.v6n12p111 URL: http://dx.doi.org/10.5539/jsd.v6n12p111

\begin{abstract}
Riparian buffers in North America usually have been designed to mitigate specific land-use impacts on watercourses, and thus often fail to preserve the full range of riparian ecological functions (e.g. wildlife habitat). This paper reviews the unique ecological characteristics of riparian areas in an attempt to formulate a widely applicable buffer delineation capable of maintaining most riparian ecosystem services.

To avoid ambiguity, the watercourse is defined in terms of its high water mark, which includes flood-prone areas and adjacent wetlands. Published data on the spatial range of riparian functions indicate that the land within $50 \mathrm{~m}$ of the water edge interacts the most with the watercourse through exchanges of matter and energy. For maximum effectiveness, the riparian buffer should be continuous (across all types of land use, ownership, and jurisdiction) and its native vegetation preserved or restored.

The delineation method has been applied using spatial analysis to a watershed in Nova Scotia, Canada. A 50-m buffer represents $15 \%$ of the watershed terrestrial area. Excluding timber harvest in this buffer decreases the total potential harvestable volume by $11 \%$ compared to provincial regulations and by $7 \%$ compared to the practices of the local forest-products company.

The simplicity of the proposed riparian buffer delineation lends itself to easy implementation by any landowner with little training and cost, a distinct advantage considering the urgency of protecting freshwater ecosystems. Moreover, continuous buffers can serve as wildlife movement corridors throughout the watershed and are thus an essential component of connectivity planning at the landscape scale.
\end{abstract}

Keywords: riparian area, conservation buffer, riparian obligate, freshwater ecosystem, riparian forest, spatial analysis, geographic information system, watershed management

\section{Introduction}

Freshwater ecosystems and resources are under serious threats as widespread expansion of forestry, agriculture, and industrial or urban development along river valleys and lakeshores has resulted in degraded water quality, impaired ecosystem services, and reduced biodiversity (Paul \& Meyer, 2001; National Research Council [NRC], 2002; Naiman \& Dudgeon, 2011). The recognition that the land in the immediate vicinity of the watercourse the riparian area - has the most influence on the aquatic ecosystem has prompted many jurisdictions in North America to adopt guidelines - either mandatory (regulations) or recommended (best management practices) controlling land use along watercourses (Young, 2000; Blinn \& Kilgore, 2001; Lee, Smyth, \& Boutin, 2004). The outcome of these guidelines is the establishment of "riparian buffers", also called "streamside management zones", which set down the width of land along a water body over which certain activities, such as timber harvest, are limited (Phillips, Swift, \& Blinn, 2000).

Most often the guidelines are concerned with streams, perennial or intermittent, whereas lakes and wetlands receive less consideration (Lee et al., 2004). The prescribed minimum buffer widths are generally $30 \mathrm{~m}$ or less, particularly in the U.S.A. (Blinn \& Kilgore, 2001), with partial timber harvest often allowed in the buffer. In fact, widths range from $10 \mathrm{~m}$ to $150 \mathrm{~m}$ depending on factors such as the terrain slope in the riparian area, the nature and size of the water body, and whether it is fish-bearing (Young, 2000; Blinn \& Kilgore, 2001; Lee et al., 2004). Although guidelines were initially concerned mostly with forestry operations, riparian buffers are now 
implemented in agricultural landscapes also (Zhang, Liu, Zhang, Dahlgren, \& Eitzel, 2010; Brinson \& Eckles, 2011) and are advocated for improving stream health and water quality in urban areas (Urban, Skelly, Burchsted, Price, \& Lowry, 2006; Day, Braioni, \& Tezer, 2008).

As our understanding of riparian ecosystems increases, riparian buffers are expected to fulfill a greater diversity of objectives beyond protecting fish habitat - the initial goal in the 1970's - to maintaining water quality, moderating stream flow, sequestering carbon, retaining old-growth forest, providing wildlife habitat, and preserving biodiversity (Wenger, 1999; Richardson, 2004; Olson, Anderson, Frissell, Welsh, \& Bradford, 2007; Brinson \& Eckles, 2011). Yet riparian buffer guidelines have not fundamentally changed since their inception, and there is increasing evidence that they are not always sufficient to prevent significant changes in structure and function of aquatic and riparian ecosystems (Richardson, Naiman, \& Bisson, 2012). There are various reasons why that may be the case. Riparian buffers vary widely among jurisdictions (municipality, county, state, or province) or land ownership (public versus private land) because they are often the result of a compromise between the conflicting interests of land use and riparian conservation (Buttle, 2002; Richardson, 2004; Olson et al., 2007). Such "compromise buffers" may be inadequate to maintain riparian functions at the level necessary to ensure the integrity of the aquatic ecosystem. Riparian buffers also vary with land use when the guidelines are primarily intended to mitigate specific land-use effects on freshwater bodies. For example, in agricultural landscapes, riparian buffers are mainly viewed as filters of fertilizers and pesticides or traps for sediment transported by overland flow (de la Crétaz \& Barten, 2007; Zhang et al., 2010). This approach tends to oversimplify the riparian area and overlook other valuable riparian functions. Overall, the inconsistencies in buffer guidelines result in a variable and/or discontinuous buffer along a stream or river flowing through different jurisdictions and land uses. Such a lack of uniformity along the watercourse can undermine buffer efficacy, as a well-buffered stream reach can still be affected adversely by an inadequate buffer upstream (Jones, Helfman, Harper, \& Bolstad, 1999; McComb, 2008).

A number of studies recommend riparian widths in excess of those prescribed by local buffer guidelines, particularly to sustain wildlife species (see reviews by Semlitsch \& Bodie, 2003; Marczak et al., 2010). However, the wider the buffer is, the less it will gain acceptance because of its encroachment on human activities, particularly in the case of small land owners for whom the buffer can represent a large proportion of their property. This consideration has resulted in the proposal of variable-width buffers where the width depends on a variety of biophysical parameters (e.g. Haberstock et al., 2000; Creed, Sass, Wolniewicz, \& Devito, 2008) and is at its widest only where it is deemed necessary for the particular conservation goal. However, the implementation of variable-width approaches rely on expert knowledge and detailed land surveys (e.g. species census, soil type determinations, terrain slope measurements, etc.). They are therefore costly, time-consuming, and difficult to enforce (O'Laughlin \& Belt, 1995; Phillips et al., 2000). Moreover, variable-width buffer guidelines tend to have limited objectives (e.g. species-specific) as their complexity greatly increases with the number of parameters to be considered (Lee et al., 2004). Fixed-width buffer prescriptions are likely to continue to endure because they are simple to implement with a minimum of training and expense, and they have the potential to preserve a wide variety of riparian functions if adequately formulated. Unfortunately, the complexity and spatial variability of aquatic and riparian ecosystems make it difficult and time-consuming to evaluate in the field the efficacy of buffer prescriptions for their diverse goals (Richardson et al., 2012). However, these field studies have greatly advanced our knowledge of the structure and functions of riparian ecosystems.

In the light of this improved understanding of riparian ecology, we re-visit the topic of riparian buffer definition in an attempt to formulate general guidelines that may better achieve the multiple goals of riparian conservation than the widespread 30-m or less partial harvest buffer prescriptions. Our approach is based on the concept that a riparian buffer should encompass the land interacting the most with the watercourse in order to preserve the range of riparian functions responsible for maintaining aquatic ecosystem health and riparian biodiversity. We propose to formulate the riparian buffer on the basis of the biophysical and ecological characteristics unique to natural riparian areas on the premises that they represent the extent of influence of the terrestrial ecosystem on the aquatic ecosystem and vice versa. To this end, the paper reviews the present knowledge of the relationships between aquatic and terrestrial ecosystems at the riparian interface. This review is framed in the context of the three components of riparian buffer definition: (1) identification of the land-water boundary, (2) determination of the buffer width measured from this boundary, and (3) regulation of land use in the buffer. To illustrate the proposed buffer delineation we apply it to a watershed in the Acadian forest of Nova Scotia, Canada, using a Geographic Information System (GIS). With this quantitative geospatial analysis, we compare the proposed buffer delineation method with current provincial buffer regulations and forestry practices in terms of land area and timber harvest sequestered in the buffer. 


\section{Riparian Buffer Definition}

\subsection{Land-Water Boundary}

Riparian zones are "transitional between terrestrial and aquatic ecosystems and are distinguished by gradients in biophysical conditions, ecological processes and biota" (NRC, 2002); in other words, they constitute the riparian ecotone (Palik, Zasada, \& Hedman, 2000; Verry, Dolloff, \& Manning, 2004) (Figure 1). In such a transitional zone, it is difficult to identify precisely the land-water boundary which, for practical reasons, is the reference for delineating riparian buffers. The difficulty in defining the land-water boundary is undoubtedly one of the causes for the apparent lack of consistency in guidelines. The name of the water body (e.g. stream, lake) may be the only definition of the water edge available in some guidelines. Even with intuitive terms such as "lake", the water's edge may not be easy to determine as it can change position considerably with seasons. For example, Nova Scotia's Wildlife Habitat and Watercourses Protection Regulations (hereafter called Nova Scotia regulations) define "watercourse" as "the bed and shore of a river, stream, lake, creek, pond, marsh, estuary or salt-water body that contains water for at least part of each year" (Government of Nova Scotia [GNS], 2003). Although this definition recognizes the intermittent nature of some water bodies, "contains water" does not clearly define the water's edge.

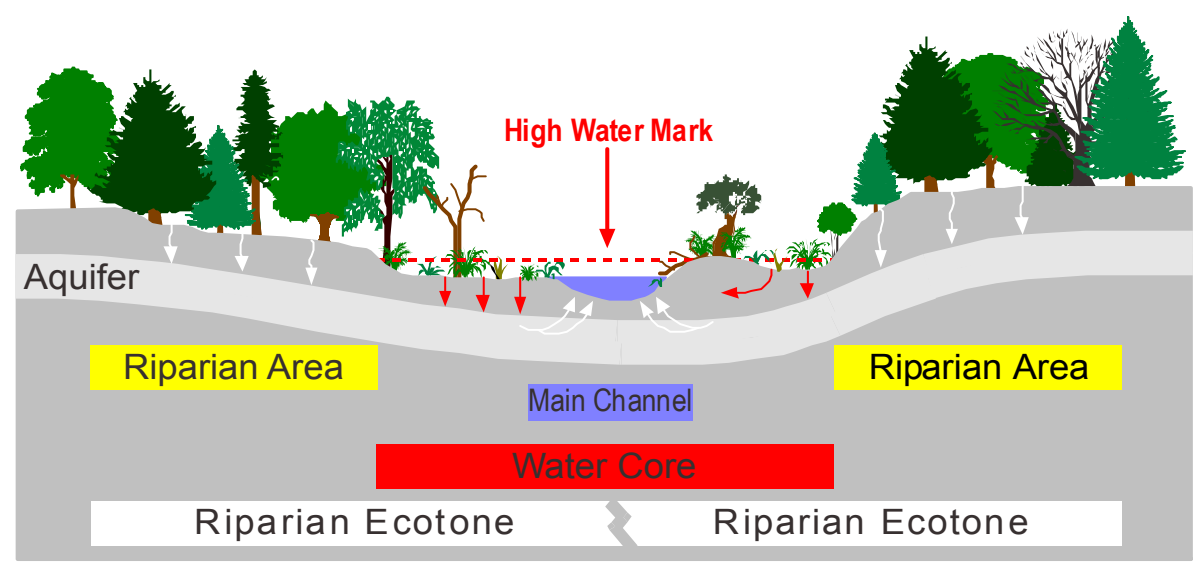

Figure 1. Schematic cross-section of the riparian ecotone and its components showing underground water flow and high water mark level

Instead of defining the watercourse as a collection of water bodies, a more consistent method is to define the extent of the watercourse in terms of "high water mark" (Naiman, Décamps, \& Pollock, 1993; Ilhardt, Verry, \& Palik, 2000) (Figure 1), also called "bankfull flow or elevation" in the case of rivers (O'Laughlin \& Belt, 1995; Verry et al., 2004). This approach has been shown to be applicable to a wide variety of stream types across North America, where bankfull elevation is reached every 1 to 2 years (United States Department of Agriculture [USDA], 2008). For clarity, we use "water core" to designate the extent of the watercourse at high water mark. The water core includes most of the low-lying areas along river channels or lakes such as wetlands or lateral channels. Indeed these low-lying areas can be considered an integral part of the water course because they store water during flood times (Wenger, 1999; Mitsch \& Gosselink, 2000) and are instrumental in replenishing the groundwater aquifer and in feeding the main channel or lake during drier periods (Luke, Luckai, Burke, \& Prepas, 2007; Creed et al., 2008) (Figure 1).

Defining the water core to be buffered on the basis of the high water mark eliminates the need to describe the different water bodies or wetlands, which can be quite complex, and recognizes the intrinsic lateral and longitudinal continuum of the watercourse (Pringle, 2001; Décamps, 2011), where all connecting water bodies are interdependent and have ecological value. This is in contrast with some guidelines that assign different buffer widths and/or land-use restrictions to different types of water body (Blinn \& Kilgore, 2001; Lee et al., 2004). For example, lakes often receive a lower level of riparian protection than streams, even though they are valuable habitat for both aquatic and riparian species and are an integral part of a region's watercourses (Bolgrien \& Kratz, 2000; NRC, 2002; Naiman \& Latterell, 2005). 
Riparian buffer guidelines commonly assign a lower level of protection (or none) to small streams, most often headwater streams (Young, 2000; Lee et al., 2004; Olson et al., 2007). Yet, headwater streams are increasingly recognized as an important determinant of downstream ecological conditions because they control the supply of energy, nutrients, sediment, and organic matter to downstream reaches (Gomi, Sidle, \& Richardson, 2002; Meyer et al., 2007a; Richardson \& Danehy, 2007). In particular, headwater streams have a strong influence on food availability for fish and other vertebrates even if they are not fish-bearing themselves (Naiman \& Latterell, 2005; Wipfli, Richardson, \& Naiman, 2007). Moreover, streams of lower order, which represent the majority of stream length (Lowe \& Likens, 2005; Meyer et al., 2007a) and drain the largest proportion of the watershed area (Gomi et al., 2002, Wipfli et al., 2007) provide diverse and unique habitat for aquatic and riparian species, particularly amphibians (Richardson, Naiman, Swanson, \& Hibbs, 2005; Meyer et al., 2007b; Olson et al., 2007; Richardson \& Danehy, 2007).

Lowe and Likens (2005) define a headwater stream as "beginning where water flowing overland first coalesces to form a discernible channel", but there is no consensus on what is the size of a "small" stream. Some guidelines define the watercourse on the basis of maps of a given scale, but some common mapping scales cannot resolve all ecologically significant small streams, or these streams are not always visible on the aerial photos on which maps are based, especially in forested landscapes (Meyer et al., 2007a; Brooks \& Colburn, 2011). Headwater stream definition may be based on stream order or area drained (e.g. less than $1 \mathrm{~km}^{2}$, Gomi et al., 2002; Meyer et al., 2007a) but these also depend on accurate mapping. "Non-fish-bearing" is often used to designate small streams, most often headwater streams, in a number of riparian guidelines (Young, 2000; Lee et al., 2004), but the absence of fish can be due to other characteristics than stream size, or to human disturbances (Olson et al., 2007). Mean annual discharge is another parameter used to define headwater streams (Young, 2000; Olson et al., 2007) and a threshold of $57 \mathrm{~L} \cdot \mathrm{s}^{-1}$ has been proposed (Richardson \& Danehy, 2007). However, water discharge is not easily measured by landowners and many measurements are necessary to obtain a representative mean annual value.

The width of a stream channel is one of the easiest parameters for anyone to measure. Richardson and Danehy (2007) suggest that the best-accepted definition of headwater streams is based on a width of less than $3 \mathrm{~m}$. Guidelines in Oregon, British Columbia, and Alberta use threshold widths of $1.5 \mathrm{~m}, 0.6 \mathrm{~m}$, and $0.5 \mathrm{~m}$ respectively (Young, 2000; Creed et al., 2008). In Nova Scotia, the watercourse protection regulations apply to streams wider than $0.5 \mathrm{~m}$, whereas for smaller streams a vehicle-exclusion zone 5-m-wide is required (GNS, 2003).

Although a specific minimum stream size is necessary to formulate unequivocal buffer guidelines, it is bound to be somewhat arbitrary as there is a continuum between what might be intuitively called a stream and a mere concentrated run-off during a strong rainfall (Meyer et al., 2007a). In the absence of a clear consensus, we propose that the water core to be buffered include stream channels above $50 \mathrm{~cm}$ in width at bankfull elevation, to include at least a portion of "small" streams.

The proposed delineation of the water core can be applied easily in the field without the need for specialized training or complex surveys. Ideally the high water mark should be determined at the time of year when water discharge is highest, provided that the particular year is not one of unusually low peak flow. Other on-the-ground observations can reveal the high water mark at other times, such as plant debris accumulation on beaches along the highest water level reached, the limit of lichen growth on shoreline rocks, or conspicuous vegetation changes such as the dominance of hydrophytes characteristic of water-logged soils (Harrelson, Rawlins, \& Potyondy, 1994; Mitsch \& Gosselink, 2000; NRC, 2002). Illustrated examples of determination of bankfull elevation for a wide variety of stream types are provided by the Stream Systems Technology Center (USDA, 2008) of the US Forest Service.

\subsection{Buffer Width}

The land-water boundary defined above lays somewhere within the riparian ecotone. For clarity we reserve the term "riparian area" to designate the terrestrial part of the ecotone, uphill from the land-water boundary (i.e. the high water mark, Figure 1). As such, the riparian area is the land that "significantly influences exchanges of energy and matter with aquatic ecosystems" (NRC, 2002). Preserving this critical land implies setting a buffer width similar to that of the riparian area, measured from the same land-water boundary. To estimate the riparian area width we consider the spatial extent of the fundamental riparian functions and attributes: (1) the processes that affect the watercourse; (2) the influence of the water course on the adjacent land, i.e. edge effects distinguishing the riparian area from uplands; and (3) the habitat range of water-dependent wildlife that, like the two previous attributes, drives the exchange of matter and energy between land and water. 


\subsubsection{Riparian Area Influence on the Watercourse}

It is now well established that water quality and aquatic habitat - not only for fish but the entire trophic chain are strongly dependent on soil and vegetation bordering the watercourse (NRC, 2002; Pusey \& Arthington, 2003; Naiman, Décamps, \& McClain, 2005; Neary, Ice, \& Jackson, 2009). The benefits of native riparian vegetation for the aquatic ecosystem, well covered in the literature and summarized in Table 1, are the object of most riparian buffer guidelines. The particular importance of riparian trees is witnessed by the fact that sometimes riparian buffers are expressed in terms of tree height (Forest Ecosystem Management Assessment Team [FEMAT], 1993; Ilhardt et al., 2000; Young, 2000). A width of one tree height - ranging from $30 \mathrm{~m}$ in eastern North America to $50 \mathrm{~m}$ in the west - is estimated to provide most of the coarse woody debris and litter to the watercourse, enough shade to prevent significant warming of its water, and the root system necessary to stabilize its banks (FEMAT, 1993; Reid \& Hilton, 1998; Young, 2000; Moore, Spittlehouse, \& Story, 2005; Muto, Kreutzweiser, \& Sibley, 2009) (Figure 2a). One tree height is consistent with reviews indicating that treed buffers on the order of $30 \mathrm{~m}$ are responsible for the majority of these riparian functions (Broadmeadow \& Nisbet, 2004; Lee et al., 2004; Groom, Dent, Madsen, \& Fleuret, 2011). Coarse woody debris provision, shading, and bank stabilisation were the main goals of the early riparian buffer guidelines, explaining the widespread use of $30 \mathrm{~m}$ as a benchmark width.

Table 1. Riparian vegetation functions and their ecological role (from Wenger, 1999; NRC, 2002; Naiman et al., 2005)

\begin{tabular}{|c|c|}
\hline $\begin{array}{l}\text { Biophysical function of } \\
\text { riparian vegetation }\end{array}$ & Ecological significance for the watercourse \\
\hline Forest litter supply & $\begin{array}{l}\text { Provides food for aquatic invertebrates, influences trophic chain, organic matter } \\
\text { storage and release }\end{array}$ \\
\hline $\begin{array}{l}\text { Coarse woody debris } \\
\text { supply }\end{array}$ & $\begin{array}{l}\text { Influences channel structure, flow characteristics, provides refugia for fish, } \\
\text { substrates for invertebrates }\end{array}$ \\
\hline Shading & $\begin{array}{l}\text { Maintains temperatures required by cool-water species of invertebrates, } \\
\text { amphibians and fish. Influences light levels and thus aquatic primary productivity } \\
\text { and trophic chain }\end{array}$ \\
\hline Root strength & Stabilises river banks \\
\hline Ground cover & $\begin{array}{l}\text { Reduces surface water flow, erosion and sediment input to the watercourse, } \\
\text { promotes water infiltration }\end{array}$ \\
\hline Uptake of nutrients & $\begin{array}{l}\text { Controls nutrients (e.g. fertilizers) input to water and reduces risks of } \\
\text { eutrophication }\end{array}$ \\
\hline $\begin{array}{l}\text { Uptake or soil adsorption } \\
\text { of contaminants }\end{array}$ & Reduces nonpoint source pollution (e.g. pesticides) and maintains water quality \\
\hline
\end{tabular}

The efficacy of riparian buffers - both retention buffers in forestry and more managed vegetated strips in agriculture - to sequester sediment particles, nutrients, and contaminants has been the object of many studies. Results in terms of buffer width are quite variable, which is to be expected considering the many factors involved, such as soil characteristics, type of riparian vegetation, chemical reactions (e.g. denitrification), and water flow paths in the riparian area, to mention only a few (Wenger, 1999; Luke et al., 2007; Neary et al., 2009). Nonetheless, reviews on the subject agree that a $30-\mathrm{m}$ width is, in many cases, adequate to maintain water quality and control the bulk of anthropogenic fluxes of sediment, nutrients, and contaminants into watercourses (Wenger, 1999; Broadmeadow \& Nisbet, 2004; Lee et al., 2004; Zhang et al., 2010). 


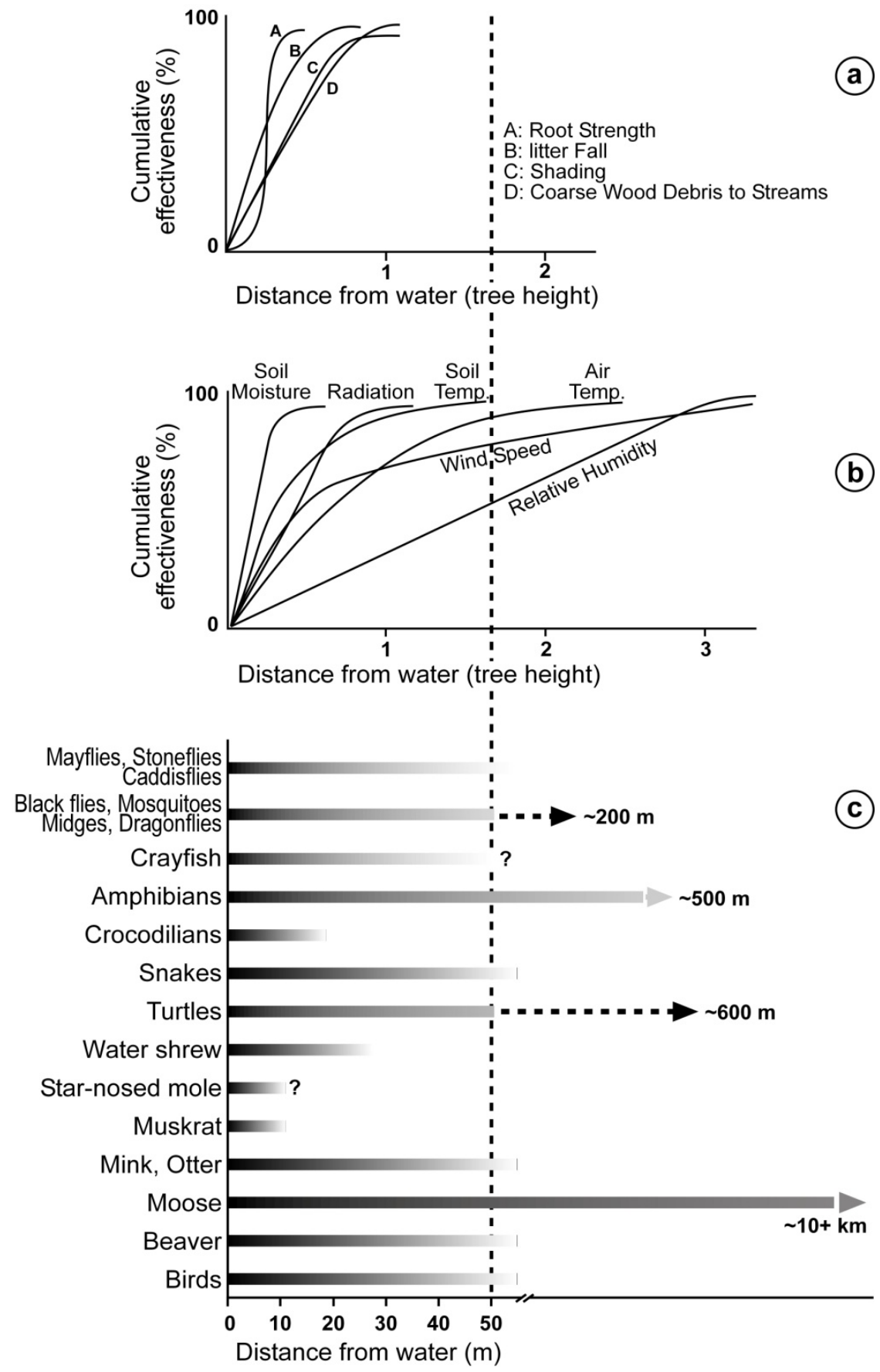

Figure 2. Riparian area width responsible for various ecological functions

(a) Cumulative proportion of riparian vegetation functions versus distance from the water's edge (adapted from FEMAT, 1993); (b) cumulative proportion of microclimatic changes versus distance from the water's edge (adapted from FEMAT, 1993); (c) estimates of riparian habitat width used by riparian obligate wildlife. Dashed arrows indicate ranges beyond $50 \mathrm{~m}$ from the water's edge used only by some individuals of the species considered (some emergent insects and turtles). Solid bars with arrow head indicate that many individuals of some of the species considered use habitat beyond $50 \mathrm{~m}$ (amphibians and moose). A question mark denotes uncertainty due to lack of data (reproduced with permission from Stoffyn-Egli \& Willison, 2011. Including wildlife habitat in the definition of riparian areas: The beaver (Castor canadensis) as an umbrella species for riparian obligate animals. Environmental Reviews 19, p. 486). The vertical dashed line shows the 50-m distance from the water's edge. The horizontal scale of (a) and (b) have been scaled assuming a tree height of $30 \mathrm{~m}$ for comparison with (c). 


\subsubsection{Contrasts Between Riparian Area and Upland}

Because of the proximity of water, the natural riparian area is characterized by gradients of soil and air microclimate parameters, ranging from aquatic edge to upland (e.g. forest interior) values (Rambo \& North, 2008). Generally, the steepest gradients in soil moisture, soil temperature, and light penetration occur within a distance of one tree height, whereas significant air humidity and temperature changes may extend further (FEMAT, 1993; Moore et al., 2005) (Figure 2b). Field studies show that in natural settings (undisturbed control sites), microclimatic gradients are strongest within 10 to $20 \mathrm{~m}$ of the water's edge and disappear at distances of 30 to $60 \mathrm{~m}$ from the water (Olson et al., 2007; Rambo \& North, 2008 and references therein).

A few North American studies have attempted to estimate riparian area width on the basis of vegetation differences. Plant species assemblages and forest structure (e.g. woody debris abundance, size and density of trees) distinct from upland vegetation have been observed within $5 \mathrm{~m}$ to $40 \mathrm{~m}$ of shorelines of streams and lakes (Spackman \& Hughes, 1995; Quinby, Willott, \& Lee, 2000; Harper \& Macdonald, 2001; Hagan, Pealer, \& Whitman, 2006; Clinton et al., 2010). In support to these North American observations, changes in vegetation along streams in cool temperate forest sites of Australia were mostly within $55 \mathrm{~m}$ of the stream edge (Mac Nally, Molyneux, Thomson, Lake, \& Read, 2008). Vegetation characteristics being dependent on soil and air microclimate, it is not surprising that the spatial gradients of both match reasonably well and suggest riparian area widths of 40 to $60 \mathrm{~m}$.

\subsubsection{Riparian Areas as Wildlife Habitat}

Buffers should be wide enough to provide adequate wildlife habitat not only for the sake of species conservation but also to preserve the integrity of the riparian area and the watercourse. It is increasingly recognized that wildlife is a major pathway of matter and energy exchanges between aquatic and terrestrial ecosystems (Naiman \& Rogers, 1997; Moore, 2006; Richardson, Zhang, \& Marczak, 2010). Wildlife activities in the riparian ecotone (e.g. foraging, predation, burrowing, wallowing, damming) significantly affect nutrient cycling (Vanni, 2002; Baxter, Fausch, \& Saunders, 2005; Ballinger \& Lake, 2006), water flow, chemistry, sediment dynamics, and morphology of the watercourse (Naiman, Pinay, Johnston, \& Pastor, 1994; Naiman \& Rogers, 1997; Butler, 2006; Moore, 2006). For example, the North American beaver, Castor canadensis, not only affects the hydrology and sedimentation characteristics of the watercourse by building dams, but can have significant effects on the terrestrial vegetation composition and succession by cutting trees and flooding low-lying areas (Rosell, Bozser, Collen, \& Parker, 2005 and references therein; Butler \& Malanson, 2005; Donkor, 2007). As a consequence, the beaver modifies the organic matter and nutrient storage and availability in streams (Naiman et al., 1994; Correll, Jordan, \& Weller, 2000), and creates habitat for many species of aquatic plants, invertebrates, fish, amphibians, birds, and mammals (See reviews by Rosell et al., 2005 and Stoffyn-Egli \& Willison, 2011). Indeed, removal of beavers can be viewed as a detrimental human disturbance of wetlands (Hood \& Bailey, 2008).

The adequacy of prescribed riparian buffers as habitat for the wide variety of species observed in riparian areas has been the object of many studies (see reviews by Semlitsch \& Bodie, 2003; Marczak et al., 2010). In general, they show that riparian buffers are important in reducing the impacts of human activities such as clear-cutting, but that local buffer guidelines often cannot sustain the same species composition and number of individuals as undisturbed sites, particularly for forest interior species (for examples, see Hannon et al., 2002; Vesely \& McComb, 2002; Shirley \& Smith, 2005). Indeed, riparian buffers, being long and narrow areas, can hardly provide interior habitat. For example, Hannon et al. (2002) argue that a 100-m-wide buffer between a clear-cut and the lake shore is all edge habitat and suggest a width of $200 \mathrm{~m}$ to maintain the passerine bird community, and even more to preserve wider-ranging species. Yet, even a $200 \mathrm{~m}$ buffer will not capture all the ecological attributes of uplands habitats and cannot, by itself, be expected to support all terrestrial species observed in riparian areas, particularly the wide-ranging ones. However, riparian buffers should be wide enough to fulfil the terrestrial habitat needs of riparian obligate animals, such as the American beaver, for example. Riparian obligate wildlife is defined as freshwater-dependent species for which the terrestrial habitat immediately adjacent to the watercourse is indispensable to complete their life history (Richardson, 2004; Anthony, O'Connell, Pollock, \& Hallett, 2003; Stoffyn-Egli \& Willison, 2011). Thus, inadequate protection of riparian habitat will eventually result in extirpation or extinction of riparian obligate species. In the context of riparian obligates conservation, the first author (P.S-E) undertook an extensive review of the terrestrial habitat requirements of riparian obligate animals in North America (Stoffyn-Egli \& Willison, 2011). This review shows that a riparian width of $50 \mathrm{~m}$ includes the terrestrial range of many species of invertebrates, amphibians, reptiles, birds and mammals, with the exception of moose and some wide-ranging amphibian species, which need upland as well as riparian habitat to complete their life cycle (Figure 2c). Stoffyn-Egli and Willison (2011) conclude that a $50 \mathrm{~m}$-wide riparian buffer 
(measured from the high water mark) in its natural state (intact native vegetation) is the minimum habitat area for supporting the majority of riparian obligate species.

In summary, the unique physical and biotic characteristics of riparian areas suggest that their width is commonly on the order of $50 \mathrm{~m}$, at least in North America. This width spans (1) the estimated riparian width necessary to ensure the aquatic health of the watercourse, (2) a large part of the biophysical gradients (e.g. microclimate, vegetation) characteristic of the riparian area, and (3) the home range necessary to sustain the majority of riparian obligate species. Therefore, we propose that in order to preserve the multiple ecological functions of riparian areas, the riparian buffer should be at least $50 \mathrm{~m}$ on each side of the watercourse.

Numerous riparian buffer guidelines prescribe wider buffers with increasing terrain slope (Young, 2000; Blinn \& Kilgore, 2001; Lee et al., 2004). This practice has been justified by the fact that riparian buffers are viewed primarily as filters for nutrients, pollutants, and sediment, and the efficacy of such filters decreases with increasing slope (Wenger, 1999). Yet, this relationship with slope is difficult and complicated to capture in riparian buffer guidelines because the efficacy of a buffer depends on the combination of many factors such as type and thickness of soil, surface roughness, vegetation, precipitation regime, and climate as well as type of land use and nature of the pollutants (Wenger, 1999; de la Crétaz \& Barten, 2007; Zhang et al., 2010). Some of these factors can vary dramatically over short distances. In our approach where the buffer is meant to preserve land-water interactions, it is gently sloping land bordering the water, not steep slopes, that will interact the most with the aquatic ecosystem and be affected the most by the proximity of the watercourse and a shallow water table (Verry et al., 2004). The proposed 50-m buffer width is measured uphill from the land-water boundary, and is a horizontal distance (i.e. map projection), not a slope length.

\subsection{Land Uses}

The discussion above emphasizes the essential role that vegetation plays in all aspects of riparian area ecological functions, thus implying that the native vegetation should be left intact in the buffer (e.g., no clear-cut or partial tree harvest) or allowed to regenerate to the point where the site-potential tree height is attained in the riparian buffer. Even partial vegetation removal can increase erosion risk and affect characteristics such as organic matter supply to the watercourse, temperature of the water, and microclimate in the riparian area, to mention only a few (England \& Rosemond, 2004; Moore et al., 2005; Lecerf \& Richardson, 2010; Groom et al., 2011). Riparian areas cover a small proportion of the landscape while supporting a disproportionately large number of species (NRC, 2002) and constitute unique habitat indispensable to riparian obligates (Anthony et al., 2003; Stoffyn-Egli \& Willison, 2011). Therefore, the proposed 50-m-wide riparian buffer should be viewed as a "reserve" and an efficient way to conserve biodiversity, including plant species, while mitigating land-use impacts on the watercourse at the same time.

The inherent hydrological continuity of river networks is their most fundamental characteristic on which depends their ecological integrity (Pringle, 2001; Décamps, 2011). The strong reciprocal linkages between aquatic and terrestrial ecosystems imply that continuity of the riparian area is necessary to maintain the health of the water course. Thus, continuity of riparian buffers, throughout agricultural and urban lands as well as forests, is crucial if the watercourse is to be protected from detrimental land uses (Crow, Baker, \& Barnes, 2000; England \& Rosemond, 2004; McComb, 2008). A relatively small gap in the buffer can be an important source of contaminants or sediment (Rabeni \& Smale, 1995; Weller, Jordan, \& Correll, 1998; Wenger, 1999; Jones et al., 1999), and the corresponding interruption of riparian functions can hamper watercourse continuity. For example, removal of shade due to riparian forest harvesting can create thermal barriers to fish migration if the stream water temperature exceeds the level fish can tolerate (Pusey \& Arthington, 2003; Stanford, Frissell, \& Coutant, 2006). Moreover, buffers must be continuous to be effective terrestrial connectivity corridors (NRC, 2002; Anthony et al., 2003; Gillies \& St. Clair, 2008).

To ensure buffer continuity, uniform guidelines must apply to all land uses, not only forestry as is the case in a number of jurisdictions (Young, 2000; Lee et al., 2004). High-impact land uses (timber harvest, agriculture, mining, industrial activities, residential development, extensive landscaping) should be excluded in the riparian buffer and others minimized (low-impact recreation, regulated fishing and hunting). Roads, bridges, and culverts should be designed to avoid barriers (e.g. elevation drops in culverts, interruption of natural shoreline by bridges) and water contamination by run-off from impervious surfaces (Wheeler, Angermeier, \& Rosenberger, 2005). Shoreline structures such as retaining walls, stabilizing berms, and flood control levees should be avoided as they impair the interactions between riparian area and the watercourse. For example, occasional flooding of the riparian area due to extreme events should not be prevented as it is an important factor in shaping and maintaining riparian biophysical characteristics, particularly vegetation composition and structure (Naiman, 
Latterell, Pettit, \& Olden, 2008; Merritt, Scott, Poff, Auble, \& Lytle, 2009). Drainage tiles in agricultural settings and storm-water drains in cities often discharge water directly into the watercourse, bypassing the riparian area and its water filtration and purification functions (Paul \& Meyer, 2001; Groffman et al., 2003).

\section{Application to the Upper Mersey River Watershed}

To illustrate the proposed riparian buffer delineation and evaluate its economic impact on forestry, we applied it to a forested watershed in Nova Scotia, Canada (Figure 3), using geospatial analysis based on a geographic information system (GIS), and compared it to present streamside management practices in terms of land area and timber harvest.

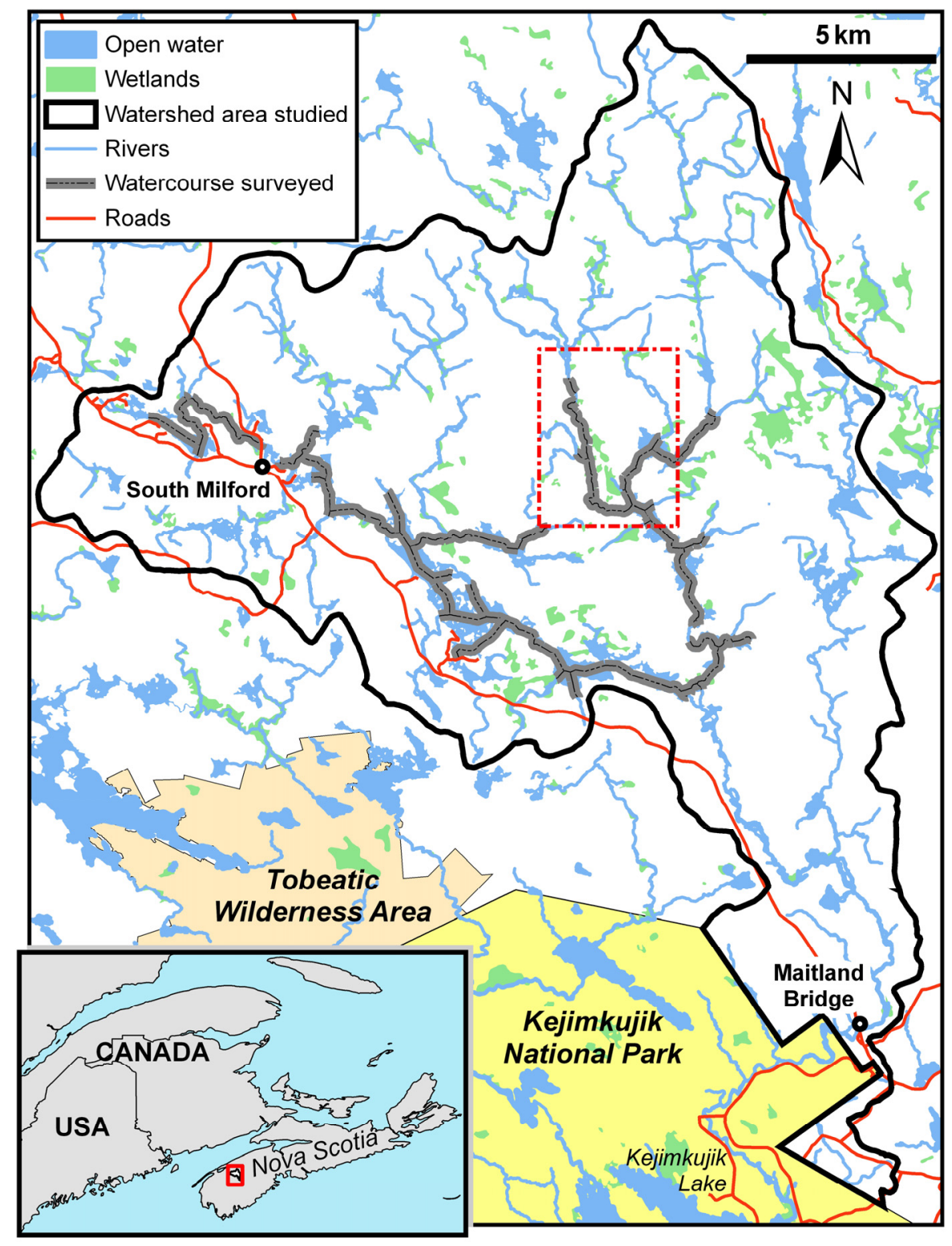

Figure 3. Upper Mersey River watershed location and map showing the watercourse portions surveyed in July 2005 and October 2008. The dashed rectangle indicates the area represented in Figure 4.

\subsection{Study Area}

The Upper Mersey River (UMR) watershed is located in Annapolis County, Nova Scotia. The area comprises all the headwaters of the Mersey River upstream of Kejimkujik Lake. The UMR flows directly into Kejimkujik National Park and National Historic Site (KNP, Figure 3), and thus the ecological integrity of the park depends 
on that of the UMR watershed. Moreover, the five counties of southwestern Nova Scotia, including Annapolis County, were designated a UNESCO Biosphere Reserve in 2001, with KNP and the adjacent Tobeatic Wilderness Area (Figure 3) as the Biosphere Reserve core (Southwest Nova Biosphere Reserve Association, 2001). The UMR watershed is a particularly appropriate place for exploring alternatives in riparian area management given that the objective of UNESCO's Biosphere Reserves is "to promote solutions to reconcile the conservation of biodiversity with its sustainable use" (UNESCO, 2000).

The UMR watershed rests on the granitic uplands of the South Mountain, which slope gently towards the southeast and are overlain by numerous drumlins of glacial origin (Nova Scotia Museum of Natural History, 1996). Rocky barrens are common, as well as poorly drained areas such as treed and open bogs. The vegetation is typical of the Acadian forest modified by fire and repeated timber harvest. The dominant species are red spruce (Picea rubens), white pine (Pinus strobus) and, locally, eastern hemlock (Tsuga canadensis), whereas balsam fir (Abies balsamea) and black spruce (Picea mariana) are more abundant in poorly drained areas between drumlins. The most abundant non-coniferous species include red maple (Acer rubrum) and white birch (Betula papyrifera), followed by yellow birch (Betula alleghaniensis), sugar maple (Acer saccharum) and red oak (Quercus rubra) (Nova Scotia Museum of Natural History, 1996).

The tributaries of the UMR are low-order streams (1 to 4) with no flood plains, stream gradients are moderate to low, and lakes are abundant (Figure 3). Although dams (mostly wooden structures) were built in the past in relation to forestry activities (log flotation, saw mills), they do not exist today and the water flow in the UMR watershed is presently unregulated (McKendry, 2008).

The major land use in the watershed is timber production for both the sawnwood and paper industries. At the time of the study, the Bowater Mersey Paper Company Limited (BMPC) owned and managed over 2/3 of the study area. Urbanization is low, mainly residences and cottages on the shores of a few lakes, and practically no agricultural activity is taking place in the watershed. Starting in the 1870s with fishing, hunting and canoeing, outdoor recreation is a strong tradition in the area (Nova Scotia Museum of Natural History, 1996).

\subsection{GIS Data}

Several spatial data layers were assembled and used in this study (Table 2). The areal extent of the data layers was limited to the UMR watershed boundary upstream from Kejimkujik Lake. This boundary was corrected in several locations where it crossed small headwater streams; it was modified manually to pass through neighbouring highest elevation points using the elevation contours data. For the purpose of buffer area and timber capability calculations, the study area was limited to the south by the boundary of KNP (Figure 3), as park land is completely protected and buffer guidelines do not apply.

The watercourse is a combination of the stream network, a continuous line network in the sense that it includes "spines" representing water flow through lakes, and of open water bodies, polygons representing lakes larger than 0.5 ha (Nova Scotia Department of Natural Resources [NSDNR], 2006) and river sections wider than $10 \mathrm{~m}$ (Service Nova Scotia and Municipal Relations [SNS\&MR], 2008) (Table 2). Discharge rates for the Mersey River below Kejimkujik Lake indicate that in May 1986 and May 1987 (years the aerial photos were taken) the flow was average, with peak flow happening in early April (Environment Canada, 2006). Therefore, the aerial extent of the open water bodies is probably slightly smaller than at high water mark, as the aerial photos were taken about a month after maximum flow on average years. Rivers narrower than $10 \mathrm{~m}$ are represented only in the stream network layer, and thus have no width per se as they are represented by lines in the database.

Reconnaissance of part of the UMR watershed was done by canoe in July 2005 and October 2008. Besides becoming familiar with the nature of local riparian areas, the goal was to get on-the-ground understanding of the wetland classification of the Forest Inventory Database (FID, Table 2). A total of $54 \mathrm{~km}$ of watercourse were surveyed (Figure 3 ) over which 26 active, four possibly active and five abandoned beaver lodges were observed. The steam network data layer was modified to include the missing outlet of Munroe Lake into Fisher Lake, located by Global Positioning System (GPS) during fieldwork. Field observations indicated that streams down to a width of approximately $50 \mathrm{~cm}$ were usually recorded in the stream network data layer. 
Table 2. GIS data layers used in this study

\begin{tabular}{|c|c|c|c|}
\hline Data Layer & $\begin{array}{l}\text { Data } \\
\text { Type }\end{array}$ & Details & Database \\
\hline UMR watershed boundary & polygon & & NSTD* \\
\hline Elevation contours & line & 5-m elevation intervals & NSTD* \\
\hline Stream network & line & $\begin{array}{l}\text { From aerial photos taken in May } 1986 \text { or May } \\
\text { 1987; revisions: September and October } 1998\end{array}$ & NSTD* \\
\hline Open water bodies & polygon & $\begin{array}{l}\text { Lakes larger than } 0.5 \text { ha } \\
\text { Rivers wider than } 10 \mathrm{~m}\end{array}$ & NSTD* and FID $\dagger$ \\
\hline Wetlands & polygon & $\begin{array}{l}\text { Four classes: General wetlands, Bogs, Treed } \\
\text { bogs \& Beaver flowage }\end{array}$ & FID $\dagger$ \\
\hline Land cover/use & polygon & $\begin{array}{l}\text { From aerial photos taken in 1992, 2001-2002 } \\
\text { and 2004-2005 }\end{array}$ & FID $\dagger$ \\
\hline $\begin{array}{l}\text { Boundaries of KNP and } \\
\text { Tobeatic Wilderness Area }\end{array}$ & polygon & & $\begin{array}{l}\text { Restricted Land } \\
\text { Use Database }\end{array}$ \\
\hline
\end{tabular}

* SNS\&MR, 2009a † NSDNR, 2009a †NSDNR, 2009b

The horizontal resolution and accuracy of the base layer for both the Nova Scotia Topographic Database (NSTD) and the Forest Inventory Database (FID) is reported as $1.0 \mathrm{~m}$ and 2.5 to $3.5 \mathrm{~m}$ respectively, and the vertical resolution and accuracy as $0.1 \mathrm{~m}$ and $2.5 \mathrm{~m}$ respectively (SNS\&MR, 2009b). Projection: UTM zone 20; Datum: NAD83; Scale: 1:10 000.

Among the four wetland categories described in the FID, field observations confirmed that "general wetlands" were the most inundated and consisted of aquatic plants whereas "bogs" were mainly ericaceous plants and mosses with more trees in the case of "treed bogs". The mapped "beaver flowage" visited was a partially inundated area with abundant grasses and thus this class is considered in this study as equivalent to "general wetlands". The location and extent of these four wetland categories corresponded well with field observations along shorelines.

In terms of land cover and use, the polygons of the FID are classified as forest or non-forest categories. For the forest categories, data on tree cover (e.g. natural stand versus plantation or clear-cut) are provided along with information on the species composition and the timber land capability $\left(\mathrm{m}^{3} \mathrm{ha}^{-1} \mathrm{yr}^{-1}\right)$ for each polygon. Besides open water bodies and wetlands, the non-forest categories include rock barrens, agricultural lands, urban areas, and road corridors. The GIS data layers were imported and processed in ArcGIS 9.1 software (ArcEditor license, ESRI, Redlands, California).

\subsection{The Models}

\subsubsection{Riparian Ecotone Model}

The riparian buffer delineation proposed in Section 2 was applied to the UMR using the following steps:

(1) Delineate the water core as comprising all open waters and adjacent "general wetlands", "beaver flowage", "bogs" and "treed bogs";

(2) Apply a 50-m buffer measured from the edge of this water core;

(3) Apply this buffer to the entirety of the water core regardless of land use (i.e. not only forestry);

(4) Assume that the vegetation is left intact, i.e. that there is no timber or other resource extraction allowed in the buffer.

This delineation is called the Riparian Area (RA) model and compared to a) the present Nova Scotia regulations (NS model) and b) the practices implemented by BMPC when it managed the land (BM model).

\subsubsection{NS Model}

The only wetland included in the Nova Scotia regulations, "marsh", is defined as "an area of permanent standing or slow moving water that is vegetated in whole or in part with aquatic or hydrophytic plants" (GNS, 2003). 
Therefore the treed and open bogs categories have not been included in the water core of the NS model because they do not match this description.

The 20-m riparian buffer width prescribed by the Nova Scotia regulations must be modified by slope as follows: "Where the land [...] has an average slope within $20 \mathrm{~m}$ of a watercourse boundary of greater than $20 \%$, the forestry operator shall increase the width of the special management zone by $1 \mathrm{~m}$ for each additional $2 \%$ of slope to a maximum of $60 \mathrm{~m}$ in width", GNS, 2003). To estimate how shoreline slope affects buffer width in the UMR watershed, a digital elevation model (DEM) was derived from the elevation contours layer (Table 2) using the "topo to raster" tool in ArcGIS. The lake polygon outlines were converted to lines and used as extra contour lines with the aim of obtaining the most accurate elevation model in the riparian area, including islands. The stream network was also used to constrain the DEM. From this DEM raster (5-m pixel size), slopes were calculated with the "slope" tool of ArcGIS, and the "contour" tool was then used to delineate areas above $20 \%$ slope. The result is that less than $1.2 \%$ of the 20 -m buffer area has slopes above $20 \%$, indicating that, according to the Nova Scotia regulations, the riparian buffer will rarely be wider than $20 \mathrm{~m}$ in the UMR watershed. Therefore, the NS model assumes a constant 20-m buffer width applied only to land categorized as "forest" in the FID.

\subsubsection{BM Model}

In the case of the BM model, treed bogs are not included in the water core as it is the only type of wetland where BMPC did not leave a buffer (Allan Smith, personal communication).

The BMPC exceeded the Nova Scotia regulations by not harvesting at all within a $20-\mathrm{m}$ buffer and by leaving an unharvested $30-\mathrm{m}$ buffer wherever more than $50 \%$ of the merchantable timber volume was being removed in the adjacent cut block (Allan Smith, personal communication). Accordingly, The BM model assumes an unharvested 30-m buffer throughout and will therefore represent an upper estimate of the merchantable volume sequestered in the riparian buffer.

As far as slope is concerned, BMPC practices followed the Nova Scotia regulations, but where it left a $30-\mathrm{m}$ buffer, it was only slopes above $40 \%$ that would require a wider buffer. Slopes in excess of $40 \%$ were not found in riparian areas on company lands in the UMR watershed (Allan Smith, personal communication). Therefore the BM model applies a 30-m buffer to all forest lands in the study area (regardless of ownership). Note that all buffer widths in this paper refer to horizontal distances as mapped in the digital data layers, not ground slope distances.

\subsection{Spatial Aanalysis}

The water core was extracted from the FID by selecting all the aquatic classes considered by the model (no treed bogs in the BM model or any bogs in the NS model) that intersect the stream network. This selected the "open water" classes and the wetlands directly adjacent to the stream network. To this initial core were added the wetlands that touch it, and the procedure was repeated until no more bog or wetland was added to the core (Figure 4; three iterations at most were necessary).

A buffer of appropriate width was then added to the final water core, and this polygon was merged with the stream network, buffered by the same width (the stream network was transformed from a line to a polygon feature during the "buffer" operation in ArcGIS). This last operation added the buffer of narrow streams that are not bordered by wetlands and eliminated any buffer area overlaps (Figure 4).

The final buffer strip (buffered polygon minus water core) was used to clip the land cover data layer and obtain the forest and non-forest attributes of the land in the buffer, such as the annual timber land capability. This procedure was repeated for each model and also for the water core of each model using a 50-m buffer, to estimate the influence of water core definition versus buffer width on the results.

The water core area for each of the three models is probably slightly underestimated because:

- The aerial photos on which the data are based were not taken exactly at the time of the highest possible water level.

- Although aerial photos are taken in the spring when deciduous trees are still leafless, some small streams may not be recorded in the stream network layer because they are obscured by tree cover.

- The streams less than $10 \mathrm{~m}$ have no width. Consequently, the buffer along the sections not bordered by wetlands is applied from the centre of the stream rather than its edge, and the buffer width may be underestimated by $5 \mathrm{~m}$ on either side at most. 




Figure 4. Open water and wetland water bodies identified in the Forest Inventory Database

The 50-m-wide riparian buffer (RA model) is shown surrounding the watercourse and all wetlands adjacent to it (water core); see Figure 3 for the location of the area depicted.

To estimate the accuracy of the results, the maximum horizontal position error of $3.5 \mathrm{~m}$ (SNS\&MR, 2009b) was applied to the water core extent of each model by shrinking or expanding its perimeter by a $3.5 \mathrm{~m}$ strip. Moreover, to estimate the maximum possible water core, the streams not bordered by wetlands (represented by a line rather than a polygon) were all assumed to have the maximum width of $10 \mathrm{~m}$ (SNS\&MR, 2008). The buffer area delineation method was repeated for each of the minimum and maximum water cores to estimate the uncertainty of the buffer area calculation. These calculations show that although the widening or narrowing of the water core causes its area to increase by $11 \%$ or decrease by $6 \%$ respectively, the lateral shift in buffer location results in less than $\pm 2 \%$ variation in buffer area (see error bars in Figure 5). For the timber land capability, the range of values represented by one class $\left( \pm 0.5 \mathrm{~m}^{3} \mathrm{ha}^{-1} \mathrm{yr}^{-1}\right)$ was used in addition to buffer area uncertainty to estimate error. The timber land capability calculations are within $\pm 12 \%$.

\subsection{Results}

The UMR watershed upstream of the KNP boundary covers almost $295 \mathrm{~km}^{2}, 86 \%$ of which is forest land, $13 \%$ is covered by open water or wetlands, and the remaining $1 \%$ is mostly residential properties, agricultural land, and roads. The water core for the NS model has an area of $27 \mathrm{~km}^{2}$, whereas including adjacent open bogs (BM model) 
adds $2 \mathrm{~km}^{2}$ and the further inclusion of adjacent treed bogs (RA model) adds another $6 \mathrm{~km}^{2}$ (Figure $5 \mathrm{a}$ ). The buffer area for each model represents $5 \%(\mathrm{NS}), 8 \%(\mathrm{BM})$ and $15 \%(\mathrm{RA})$ of the terrestrial area $\left(257 \mathrm{~km}^{2}\right.$, no open water or wetlands) of the watershed.

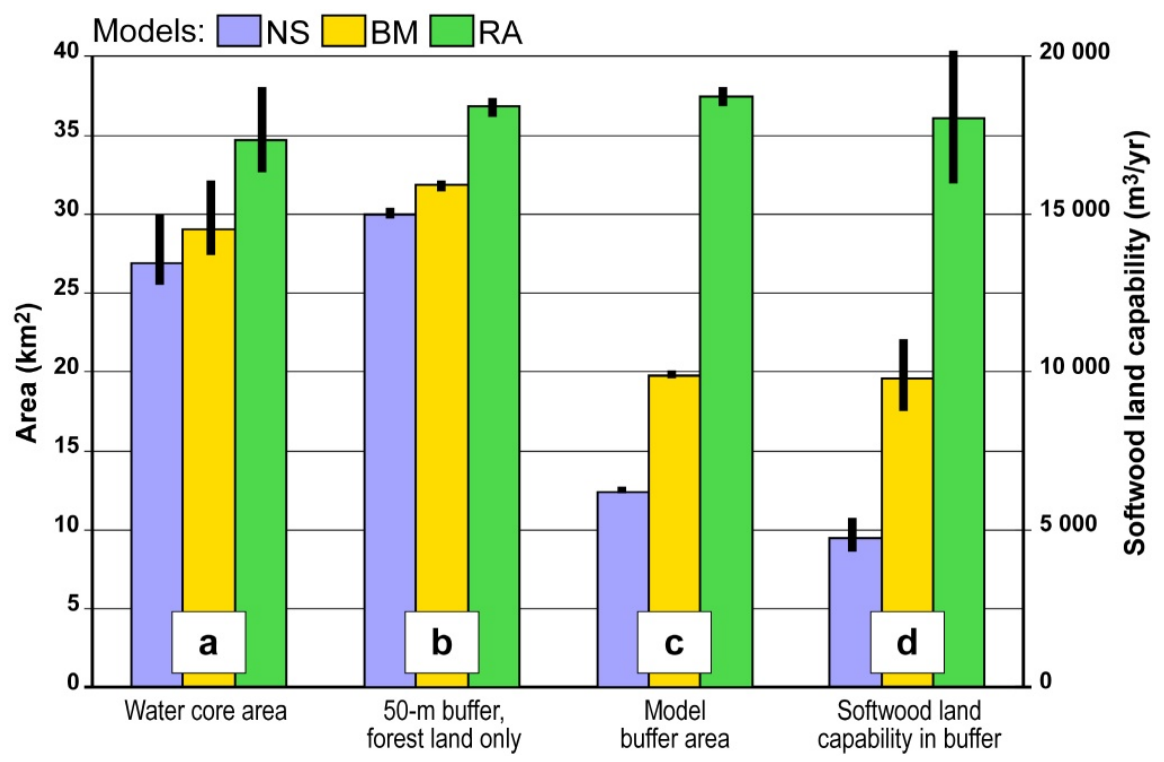

Figure 5. Spatial analysis results for the three models

a) Water core area (NS: no bogs; BM: no treed bogs; RA: bogs included); b) area of same buffer width (50 m, in forest land only) applied to each water core; c) buffer area for each model (buffer widths are NS: $20 \mathrm{~m}$; BM: 30 m; RA: $50 \mathrm{~m}$, all lands); d) commercial softwood land capability not harvested in the buffer area for each model. The error bars were calculated on the basis of a $\pm 3.5 \mathrm{~m}$ maximum horizontal position error of the GIS data, and the range of value classes reported for timber land capability $\left( \pm 0.5 \mathrm{~m}^{3} \mathrm{ha}^{-1} \mathrm{yr}^{-1}\right.$; see section 3.4 for details).

To estimate how much the difference in water core definition affects the buffer area, an identical $(50 \mathrm{~m})$ buffer was applied to each water core (Figure 5b). The results show that the $50-\mathrm{m}$ buffer areas in forest land differ by approximately the same proportion as their water core areas. Therefore, the differences in buffer area among the three models (Figure 5c) are mostly due to the difference in buffer widths rather than water core size differences and, in the case of the RA model, to the fact that the buffer applies to all lands, not only forest.

The annual softwood capability (the hardwood capability estimated in the FID is negligible) in the 30-m riparian buffer left unharvested by BMPC is on the order of $9800 \mathrm{~m}^{3} \mathrm{yr}^{-1}$ whereas a $50-\mathrm{m}$-wide unharvested riparian buffer (RA model) has a capability of $18000 \mathrm{~m}^{3} \mathrm{yr}^{-1}$ (Figure 5d). In other words, $8 \%$ and $14 \%$ of the total timber-growing capability of the watershed $\left(\sim 125700 \mathrm{~m}^{3} \mathrm{yr}^{-1}\right)$ are located in the $30-\mathrm{m}$ and $50-\mathrm{m}$ buffers respectively. The lower value for the BM model is not only due to a narrower buffer strip but to the fact that a larger proportion of the buffer is composed of treed bogs rather than productive forest because treed bogs are not included in the water core, and thus contribute to the buffer area of the stream, lake or wetland they border.

In the case of the NS model, the 20-m buffer represents a softwood capability of $6100 \mathrm{~m}^{3} \mathrm{yr}^{-1}$ (5\% of the total watershed capability). However, only a fraction of it is available for harvest because the regulations only allow harvesting down to a remaining basal area of $20 \mathrm{~m}^{2} \mathrm{ha}^{-1}$ (GNS, 2003). Merchantable basal area (trees above $9 \mathrm{~cm}$ in diameter at breast height) surveys in mature, productive stands adjacent to watercourses (provided by Allan Smith, BMPC) indicated that $42 \%$ of the area of stands surveyed had basal areas less than or equal to $20 \mathrm{~m}^{2} \mathrm{ha}^{-1}$. In the remaining $58 \%$, the average harvestable softwood basal area (basal area above the quantity of softwood that, along with all other species, amounted to $20 \mathrm{~m}^{2} \mathrm{ha}^{-1}$ ) was $40 \%$ of the total softwood basal area. By applying this proportion to the capability of the stands and extrapolating to the whole watershed, only $23 \%$ of the softwood capability in the 20-m buffer can be harvested $\left(1400 \mathrm{~m}^{3} \mathrm{yr}^{-1}\right)$ and $4 \%\left(4700 \mathrm{~m}^{3} \mathrm{yr}^{-1}\right.$, Figure $\left.5 \mathrm{~d}\right)$ of the total softwood capability of the watershed is excluded from harvest by the Nova Scotia regulations.

In summary, compared to the Nova Scotia regulations, the BM model reduces the harvestable softwood capability of the watershed by $4 \%\left(5100 \mathrm{~m}^{3} \mathrm{yr}^{-1}\right)$, and the RA model by $11 \%\left(13,300 \mathrm{~m}^{3} \mathrm{yr}^{-1}\right)$. 


\subsection{Discussion}

A 50-m no-harvest buffer results in a drop of 7\% in total harvestable capability of the UMR watershed compared to BMPC practices. Although this loss in resource and revenue is not trivial for the forest-products industry, it may be an acceptable trade-off for a $90 \%$ increase in buffer surface area in forested lands and concurrent safeguard of riparian functions. The value of freshwater ecosystems' goods and services is considerable (e.g. potable water, fishing, flood control, aquifer replenishment; Costanza et al., 1997) and the maintenance of riparian services will help fulfil the sustainability goals of the Southwest Nova Biosphere Reserve. For example, water quality is essential in a watershed where the majority of residents rely on wells for potable water and pristine riparian areas are valued where outdoor activities such as fishing and canoeing are important drivers for the local tourism industry.

In terms of resources and land use, the definition of the water core is not costly: wetlands do not support much economically valuable timber (even treed bogs are listed as having stunted hardwood and softwood species) and cannot support heavy machinery. Similarly, these wetlands have little agricultural value and are definitely not adequate as residential areas due to poorly drained soils and frequent floods.

Mapping riparian buffers is valuable for assessment and planning purposes. The method used here to identify the water core is based on geomorphology and requires only basic data readily available (at least in North America) such as hydrography (streams, lakes and wetlands) and elevation data. However, it is important that the hydrography data layers be a reasonably complete representation of the high water mark and wetlands. If data (e.g. aerial photos) have not been collected during the wettest season or if the scale is too small to show small streams, geomorphology and topography must be relied upon more heavily to delineate the water core. In a study similar to ours, Holmes and Goebel (2011) delineated manually "the likely extent of the functional riparian areas" on the basis of topography. They then added a tree-height width to this area. It should be noted that they call their method a functional buffer delineation rather than fixed-width buffer because their point of reference is not the high water mark. This illustrates the fact that the controversy between fixed and variable width buffers is often only a consequence of differences in the definition of the land-water boundary.

It should be kept in mind that digital maps are not necessarily an accurate and complete representation of the landscape. Therefore, ultimate delineation of the water core and the riparian buffer should be done on the ground, and this is why a simple method, requiring only linear measurements and direct high-water-level observations, is valuable. Slope measurements will be necessary to match on-the-ground delineation with maps only in the case of steep slopes (for example, there is a $10 \%$ difference between horizontal and slope lengths for a slope of $45 \%$ ).

\section{Implications for Watershed Management}

The holistic approach of implementing a buffer that encompasses the majority of the riparian area supports the concept of a single-width buffer because it recognises the multiplicity of functions (Luke et al., 2007) of any portion of the riparian area and thus the multi-purpose (Buttle, 2002) nature of the buffer. As biodiversity in riparian areas is due in part to "ecological diversity" (Naiman et al., 1993) - the variety of patches of different habitats further modulated by seasons and disturbances - all reaches of a watercourse deserve an equal level of protection and will enhance resiliency of the aquatic and riparian ecosystems. If sufficiently wide (i.e on the order of $50 \mathrm{~m}$ as suggested by published studies), a single-width buffer is not an over-simplification of the riparian area, but is consistent with a precautionary approach of preserving the entire riparian community, not only a single species or site-specific ecosystem function. As such, the proposed riparian buffer delineation is relevant in a wide range of ecological settings, and thus geographic locations.

The advantage of the proposed riparian buffer delineation is that its implementation does not require advanced training or site-specific surveys and thus can be applied with little investment of time and money by everyone, from the forestry professional and the natural resources manager to the local resident or woodlot owner. This delineation is easily mapped using GIS for land-use planning and management purposes, although it is indispensable to ground truth the resulting buffer. Yet, for land owners who do not have access to these mapping tools, or when the data are inadequate, local knowledge of high water level and straightforward measurement of the 50-m distance is all that is required to apply a riparian buffer which is a fairly good approximation of the riparian area. This simple yet ecologically sound riparian buffer delineation can compensate for what it lacks in accuracy and complexity by virtue of its capacity for rapid implementation, thus avoiding the phenomenon of "paralysis by over-analysis" (Roberge \& Angelstam, 2004).

We recognize that this review relies more heavily on studies of headwater streams in forested areas of the Pacific Northwest and Eastern Seaboard of North America. Besides the fact that this emphasis reflects that of the published literature, it is in these areas that the most pristine conditions can be found to study natural riparian 
areas. Yet, the riparian functions and attributes reviewed are fundamental and can be expected to apply to various types of streams and ecosystems. For example, a distinctive feature of higher order lowland rivers is their associated floodplains, where sediment and vegetation composition and structure are determined by disturbances such as regular flooding and channel migration (Naiman, Bilby, \& Bisson, 2000; Luke et al., 2007; Naiman et al., 2008; Merritt et al., 2009). Our definition of the water core (extent at high water mark) automatically includes, and thus maintains, the floodplain. The riparian buffer will preserve the adjoining slope and terrace, which contribute significantly to riparian plant diversity (Goebel, Palik, \& Pregitzer, 2003). Because the riparian functions listed in Table 1 are independent of water-core size, the 50-m buffer will be as effective in providing ecological services and supporting biodiversity in a lowland river as in an upland stream.

Our review may be biased toward forested regions, but many non-forested riparian areas are so only because of human alteration. In these cases, riparian area restoration, including planting of trees native to the region, is necessary to achieve an effective riparian buffer (Correll, 2005; Lake, Bond, \& Reich, 2007). In ecoregions such as prairies or semi-deserts, trees grow almost exclusively along watercourses (e.g. cottonwood: Populus fremontii, bur oak: Quercus macrocarpa, honey locust: Gleditsia triacanthos). Therefore, tree-related riparian functions (Table 1) are still relevant in watercourses of these non-forested ecoregions.

For riparian buffers to be truly effective, consistent regulations have to be applied throughout the watershed, regardless of land use (forestry, agriculture, urban), ownership (public or private), or administrative boundaries (McComb, 2008). Implementing a continuous buffer throughout a watershed can be challenging and time-consuming, and a simple delineation method can only help in this respect. A continuous buffer can be achieved only incrementally, and the task can be divided into meaningful segments by splitting the watershed into sub-watersheds upstream of points of confluence, such as the case study site, which comprises all the tributaries of the Mersey River upstream from Kejimkujik Lake. As most passive movements of organisms and materials are in the downstream direction, each individual sub-watershed is self-contained and relatively independent of the remainder of the watershed (Lowe \& Likens, 2005), except for active movements in the upstream direction (e.g. swimmers). Therefore, riparian protection of these sub-watersheds is a necessary step toward integrated management of the whole river basin and an expedient way to progress in that direction. But ultimately, downstream reaches must be protected or restored as well to allow movements in the upstream direction, most notably anadromous fish migrations. This proves more difficult as human activities are often concentrated along river mouths and estuaries. On the other hand, implementing the proposed water core and riparian buffer delineation would help decrease flood damage to property by excluding development in the most flood-prone areas of river valleys.

It should be noted that the water core does not include the area flooded during exceptionally high water (e.g. 50or 100-year flood). Therefore, at least part of the riparian area (or more in the case of low-relief terrain) will be occasionally flooded, an infrequent disturbance that is integral to riparian ecology (Naiman et al., 2000). Moreover, watercourses are evolving constantly, reshaped by erosion, sedimentation, and the activities of large animals such as beavers, and it is inevitable that delineation of the water core and the riparian buffer may have to be readjusted with time, particularly in the more dynamic reaches, regardless of the method by which the riparian area is defined.

Although it is demonstrated that riparian buffers are essential for maintaining the ecological health of watercourses, they are linear reserves where edge effects dominate (Hannon et al., 2002; Mascarúa López, Harper, \& Drapeau, 2006). As such, the efficacy of a 50-m reserve can be undermined by its vulnerability to invasion by exotic species (Hood \& Naiman, 2000; Naiman et al., 2005), by wind-throws along clear-cut edges (Reid \& Hilton, 1998; Ruel, Pin, \& Cooper, 2001), and by erosion in the case of buffers on steep slopes. Multiple-zone buffers (Semlitsch \& Bodie, 2003; Correll, 2005) or a progressive "gradient of impact" increasing away from the water's edge (Reid \& Hilton, 1998; Crow et al., 2000; Palik et al., 2000) have been proposed to alleviate edge effects. In the case of forested landscapes such as the UMR watershed, mitigation of edge effects on the riparian buffer could be achieved by a transition zone of partial harvest separating any clearcut from the 50-m no-harvest buffer.

Aquatic and riparian area health is predicated on the maintenance of hydrologic connectivity (Pringle, 2001; Décamps, 2011) and natural water discharge fluctuations in magnitude, frequency, duration and timing (Naiman et al., 2008). Therefore, dams and flow control structures are detrimental to the watercourse and riparian area regardless of buffer width and level of protection. Such structures should be removed or modified and operated to maintain minimum levels of water, natural flow fluctuations and passage for migrating species (e.g. salmon). In the case of the Mersey River, six hydroelectric dams downstream from KNP (McKendry, 2008) are likely to affect the species and genetic make-up of aquatic life in the park and the UMR by hampering migrations. 
At the landscape scale, the watercourse is the focal point of the watershed and integrates the effect of all natural processes and land-use activities in this watershed in both space (Stein \& Ambrose, 2001; Naiman et al., 2002) and time (Zhang, Richardson, \& Pinto, 2009). Although difficult to quantify, relationships between intensity of land uses and stream condition indicators (e.g. hydrologic regime, channel characteristics, and fish or invertebrate community health and composition) suggest that signs of stream degradation become detectable when forest harvesting covers more than $20 \%$ of the watershed (Buttle, 2011), agriculture more than 50\% (Gergel, Turner, Miller, Melack, \& Stanley, 2002), or urban areas (impervious surfaces, highways) more than 10\% (Paul \& Meyer, 2001; Wheeler et al., 2005). The surrounding landscape matrix will affect riparian-area biodiversity even with the implementation of a buffer (Rodewald \& Bakermans, 2006; Ficetola, Padoa-Schioppa, \& De Bernardi, 2009).

The examples above are evidence that the watercourse is intimately linked to the whole watershed, particularly through underground water flow (Neary et al., 2009). In this context, the buffer delineation method proposed in this paper focuses on surface flow and on "adjacent" wetlands for simplicity. However, it is recognized that "disconnected" open waters or wetlands have ecological and conservation value and can be connected to the watercourse through subsurface flow (Semlitsch \& Bodie, 1998; Meyer et al., 2007a). The implication is that a riparian buffer cannot by itself mitigate all land-use impacts on the watercourse and that sound management practices have to be applied throughout the watershed (Shandas \& Alberti, 2009; Zhang et al., 2009; Buttle, 2011).

In land-use planning, riparian-area protection is an effective way to protect a disproportionably large amount of biodiversity but it is not sufficient by itself. A $50-\mathrm{m}$ buffer alone cannot provide the requirements of forest interior species or the functions of large blocks of old-growth forest (Hannon et al., 2002; Potvin \& Bertrand, 2004; Mascarúa López et al., 2006). Connecting intact upland forest patches with the riparian area is necessary for riparian obligate species depending also on uplands for their life cycle, i.e. some amphibian species and moose (Olson et al., 2007; Stoffyn-Egli \& Willison, 2011). Effective connection between watersheds is of particular importance to facilitate dispersal of riparian obligates. Therefore, priority should be given to leaving terrestrial corridors between the headwater tributaries of adjacent watersheds, where gaps are smallest (Olson \& Burnett, 2009). In the case of the UMR, many such watershed links would be less than $1 \mathrm{~km}$ long, sometimes as short as $300-400 \mathrm{~m}$. On the other hand, riparian buffers not only facilitate movement of riparian wildlife, they also serve as movement corridors for upland species (NRC, 2002; Anthony et al., 2003; Gillies \& St. Clair, 2008), provided they are connected to upland habitat. As such, the riparian buffer is an essential component of habitat conservation and connectivity planning at the landscape level.

\section{Acknowledgements}

We are grateful to the staff of the Dalhousie University GIS Centre, Jennifer Strang, Jennifer Milne, James Boxall, Ian Bryson and Raymond Jahncke, and of the Applied Geomatics Research Group, David Colville and Heather Stewart, for their help in gathering data and using GIS software. Allan Smith of the Bowater Mersey Paper Company provided information on forestry practices and data for the study area, and comments on the contents of this paper. Special thanks go to Dr. Martin Willison for insightful discussions and editorial comments. Drs. Gunter Muecke and Cathy Conrad reviewed earlier versions of this manuscript. Financial support for this research was provided by the Mersey Tobeatic Research Institute, The School for Resource and Environmental Studies Thesis Research Award, and the Environmental Systems Research Institute (ESRI Canada) 2006 GIS Scholarship which included ArcEditor software.

\section{References}

Anthony, R. G., O'Connell, M. A., Pollock, M. M., \& Hallett, J. G. (2003). Associations of mammals with riparian ecosystems in Pacific Northwest forests. In C. J. Zabel \& R. G. Anthony (Eds.), Mammal community dynamics: Management and conservation in the coniferous forests of western North America (pp. 510-563). Cambridge, UK: Cambridge University Press. http://dx.doi.org/10.1017/CBO9780511615757.016

Ballinger, A., \& Lake, P. S. (2006). Energy and nutrient fluxes from rivers and streams into terrestrial food webs. Marine \& Freshwater Research, 57(1), 15-28. http://dx.doi.org/10.1071/MF05154

Baxter, C. V., Fausch, K. D., \& Saunders, W. C. (2005). Tangled webs: Reciprocal flows of invertebrate prey link streams and riparian zones. Freshwater Biology, 50(2), 201-220. http://dx.doi.org/10.1111/j.1365-2427.2004.01328.x 
Blinn, C. R., \& Kilgore, M. A. (2001). Riparian management practices - A summary of state guidelines. Journal of Forestry, 99(8), 11-17.

Bolgrien, D. W., \& Kratz, T. K. (2000). Lake riparian areas. In E. S. Verry, J. W. Hornbeck \& C. A. Dolloff (Eds.), Riparian management in forests of the continental Eastern United States (pp. 207-218). Boca Raton, FL, USA: Lewis Publishers.

Brinson, M. M., \& Eckles, S. D. (2011). U.S. Department of Agriculture conservation program and practice effects on wetland ecosystem services: A synthesis. Ecological Applications, 21(3), S116-S127. http://dx.doi.org/10.1890/09-0627.1

Broadmeadow, S., \& Nisbet, T. R. (2004). The effects of riparian forest management on the freshwater environment: A literature review of best management practice. Hydrology \& Earth System Sciences, 8(3), 286-305. http://dx.doi.org/10.5194/hess-8-286-2004

Brooks, R. T., \& Colburn, E. A. (2011). Extent and channel morphology of unmapped headwater stream segments of the Quabbin watershed, Massachusetts. Journal of the American Water Resources Association, 47(1), 158-168. http://dx.doi.org/10.1111/j.1752-1688.2010.00499.x

Butler, D. R. (2006). Human-induced changes in animal populations and distributions, and the subsequent effects on fluvial systems. Geomorphology, 79(3-4), 448-459. http://dx.doi.org/10.1016/j.geomorph.2006.06.026

Butler, D. R., \& Malanson, G. P. (2005). The geomorphic influences of beaver dams and failures of beaver dams. Geomorphology, 71(1-2), 48-60. http://dx.doi.org/10.1016/j.geomorph.2004.08.016

Buttle, J. M. (2002). Rethinking the donut: The case for hydrologically relevant buffer zones. Hydrological Processes, 16(15), 3093-3096. http://dx.doi.org/10.1002/hyp.5066

Buttle, J. M. (2011). The effects of forest harvesting on forest hydrology and biogeochemistry. In D. F. Levia et al. (Eds.), Forest hydrology and biogeochemistry: Synthesis of past research and future directions. Ecological Studies, 216, 659-677. http://dx.doi.org/10.1007/978-94-007-1363-5_33

Clinton, B. D., Vose, J. M., Knoepp, J. D., Elliott, K. J., Reynolds, B. C., \& Zarnoch, S. J. (2010). Can structural and functional characteristics be used to identify riparian zone width in southern Appalachian headwater catchments? Canadian Journal of Forest Research, 40, 235-253. http://dx.doi.org/10.1139/X09-182

Correll, D. L. (2005). Principles of planning and establishment of buffer zones. Ecological Engineering, 24(5), 433-439. http://dx.doi.org/10.1016/j.ecoleng.2005.01.007

Correll, D. L., Jordan, T. E., \& Weller, D. E. (2000). Beaver pond biogeochemical effects in the Maryland Coastal Plain. Biogeochemistry, 49(3), 217-239. http://dx.doi.org/10.1023/A:1006330501887

Costanza, R., d'Arge, R., deGroot, R., Farber, S., Grasso, M., Hannon, B., ... vandenBelt, M. (1997). The value of the world's ecosystem services and natural capital. Nature, 387(6630), 253-260. http://dx.doi.org/10.1038/387253a0

Creed, I. F., Sass, G. Z., Wolniewicz, M. B., \& Devito, K. J. (2008). Incorporating hydrologic dynamics into buffer strip design on the sub-humid Boreal Plain of Alberta. Forest Ecology \& Management, 256(11), 1984-1994. http://dx.doi.org/10.1016/j.foreco.2008.07.021

Crow, T. R., Baker, M. E., \& Barnes, B. V. (2000). Diversity in riparian landscapes. In Riparian management in forests of the continental Eastern United States. In E. S. Verry, J. W. Hornbeck \& C. A. Dolloff (Eds.), Riparian management in forests of the continental Eastern United States (pp. 43-66). Boca Raton, FL, USA: Lewis Publishers.

Day, E., Braioni, G., \& Tezer, A. (2008). Integrating aquatic habitat management into urban planning. In I. Wagner, J. Marsalek \& P. Breil (Eds.), Aquatic habitats in sustainable urban water management: Science, policy and practice (pp. 107-127). Paris, France: UNESCO Publishing.

de la Crétaz, A. L., \& Barten, P. K. (2007). Land use effects on streamflow and water quality in the northeastern United States. Boca Raton, FL, USA: Taylor \& Francis.

Décamps, H. (2011). River networks as biodiversity hotlines. Comptes Rendus Biologies, 334(5-6), 420-434. http://dx.doi.org/10.1016/j.crvi.2011.03.002

Donkor, N. T. (2007). Impact of beaver (Castor canadensis kuhl) foraging on species composition of boreal forests. In E. A. Johnson \& K. Miyanishi (Eds.), Plant disturbance ecology (pp. 579-602). New York, NY, USA: Academic Press. http://dx.doi.org/10.1016/B978-012088778-1/50020-0 
England, L., \& Rosemond, A. (2004). Small reductions in forest cover weaken terrestrial-aquatic linkages in $\begin{array}{lllll}\text { headwater } & \text { streams. } & \text { Freshwater } & \text { Biology, } & 49(6),\end{array}$ $\mathrm{http}: / / \mathrm{dx}$. doi.org/10.1111/j.1365-2427.2004.01219.x

Environment Canada. (2006). Archived hydrometric data - Mersey River below George Lake. Retrieved March 16, 2009, from http://www.wsc.ec.gc.ca/hydat/H2O/index_e.cfm?cname=WEBfrmMeanReport_e.cfm\& RequestTimeout $=300$

FEMAT - Forest Ecosystem Management Assessment Team. (1993). Forest ecosystem management: An ecological, economic, and social assessment. Washington, DC, USA: USDA Forest Service.

Ficetola, G. F., Padoa-Schioppa, E., \& De Bernardi, F. (2009). Influence of landscape elements in riparian buffers on the conservation of semiaquatic amphibians. Conservation Biology, 23(1), 114-123. http://dx.doi.org/10.1111/j.1523-1739.2008.01081.x

Gergel, S. E., Turner, M. G., Miller, J. R., Melack, J. M., \& Stanley, E. H. (2002). Landscape indicators of human impacts to riverine systems. Aquatic Sciences, 64(2), 118-128. http://dx.doi.org/10.1007/s00027-002-8060-2

Gillies, C. S., \& St. Clair, C. C. (2008). Riparian corridors enhance movement of a forest specialist bird in fragmented tropical forest. Proceedings of the National Academy of Sciences, 105(50), 19774-19779. http://dx.doi.org/10.1073/pnas.0803530105

GNS - Governement of Nova Scotia. (2003). Wildlife habitat and watercourses protection regulations 2009. Retrieved July 6, 2009, from http://www.gov.ns.ca/just/regulations/regs/fowhwp.htm

Goebel, P. C., Palik, B. J., \& Pregitzer, K. S. (2003). Plant diversity contributions of riparian areas in watersheds of the northern Lake States, USA. Ecological Applications, 13(6), 1595-1609. http://dx.doi.org/10.1890/01-5314

Gomi, T., Sidle, R. C., \& Richardson, J. S. (2002). Understanding processes and downstream linkages of $\begin{array}{llll}\text { headwater systems. } & \text { Bioscience, } & \text { 905-916. }\end{array}$ http://dx.doi.org/10.1641/0006-3568(2002)052[0905:UPADLO]2.0.CO;2

Groffman, P. M., Bain, D. J., Band, L. E., Belt, K. T., Brush, G. S., Grove, J. M., ... Zipperer, W. C. (2003). Down by the riverside: Urban riparian ecology. Frontiers in Ecology and the Environment, 1(6), 315-321. http://dx.doi.org/10.2307/3868092

Groom, J. D., Dent, L., Madsen, L. J., \& Fleuret, J. (2011). Response of western Oregon (USA) stream temperatures to contemporary forest management. Forest Ecology \& Management, 262(8), 1618-1629. http://dx.doi.org/10.1016/j.foreco.2011.07.012

Haberstock, A. E., Nichols, H. G., DesMeules, M. P., Wright, J., Christensen, J. M., \& Hudnut, D. H. (2000). Method to identify effective riparian buffer widths for Atlantic salmon habitat protection. Journal of the $\begin{array}{lllll}\text { American } \quad \text { Water } & \text { Resources }\end{array}$ http://dx.doi.org/10.1111/j.1752-1688.2000.tb05726.x

Hagan, J. M., Pealer, S., \& Whitman, A. A. (2006). Do small headwater streams have a riparian zone defined by plant communities? Canadian Journal of Forest Research, 36(9), 2131-2140. http://dx.doi.org/10.1139/X06-114

Hannon, S. J., Paszkowski, C. A., Boutin, S., DeGroot, J., Macdonald, S. E., Wheatley, M., \& Eaton, B. R. (2002). Abundance and species composition of amphibians, small mammals, and songbirds in riparian forest buffer strips of varying widths in the boreal mixedwood of Alberta. Canadian Journal of Forest Research, 32(10), 1784-1800. http://dx.doi.org/10.1139/X02-092

Harper, K. A., \& MacDonald, S. E. (2001). Structure and composition of riparian boreal forest: New methods for analyzing edge influence. Ecology, 82(3), 649-659. http://dx.doi.org/10.2307/2680186

Harrelson, C. C., Rawlins, C. L., \& Potyondy, J. P. (1994). Stream channel reference sites: An illustrated guide to field technique. USDA Forest Service General Technical Report RM-245. Retrieved from http://www.stream.fs.fed.us/publications/PDFs/RM245E.PDF

Holmes, K. L., \& Goebel, P. C. (2011). A functional approach to riparian area delineation using geospatial methods. Journal of Forestry, 109(4), 233-241. 
Hood, G. A., \& Bayley, S. E. (2008). Beaver (Castor canadensis) mitigate the effects of climate on the area of open water in boreal wetlands in western Canada. Biological Conservation, 141(2), 556-567. http://dx.doi.org/10.1016/j.biocon.2007.12.003

Hood, W. G., \& Naiman, R. J. (2000). Vulnerability of riparian zones to invasion by exotic vascular plants. Plant Ecology, 148(1). http://dx.doi.org/105-114.10.1023/A:1009800327334

Ilhardt, B. L., Verry, E. S., \& Palik, B. J. (2000). Defining riparian areas. In E. S. Verry, J. W. Hornbeck \& C. A. Dolloff (Eds.). Riparian management in forests of the continental Eastern United States (pp. 23-42). Boca Raton, FL, USA: Lewis Publishers.

Jones, E. B. D., Helfman, G. S., Harper, J. O., \& Bolstad, P. V. (1999). Effects of Riparian Forest Removal on Fish Assemblages in Southern Appalachian Streams. Conservation Biology, 13(6) 1454-1465. http://dx.doi.org/10.1046/j.1523-1739.1999.98172.x

Lake, P. S., Bond, N., \& Reich, P. (2007). Linking ecological theory with stream restoration. Freshwater Biology, 52(4), 597-615. http://dx.doi.org/10.1111/j.1365-2427.2006.01709.x

Lecerf, A., \& Richardson, J. S. (2010). Litter decomposition can detect effects of high and moderate levels of forest disturbance on stream condition. Forest Ecology \& Management, 259, 2433-2443. http://dx.doi.org/10.1016/j.foreco.2010.03.022

Lee, P., Smyth, C., \& Boutin, S. (2004). Quantitative review of riparian buffer width guidelines from Canada and the United States. Journal of Environmental Management, 70(2), 165-180. http://dx.doi.org/10.1016/j.jenvman.2003.11.009

Lowe, W. H., \& Likens, G. E. (2005). Moving headwater streams to the head of the class. Bioscience, 55(3), 196-197. http://dx.doi.org/10.1641/0006-3568(2005)055[0196:MHSTTH]2.0.CO;2

Luke, S. H., Luckai, N. J., Burke, J. M., \& Prepas, E. E. (2007). Riparian areas in the Canadian boreal forest and linkages with water quality in streams. Environmental Reviews, 15, 79-97. http://dx.doi.org/10.1139/A07-001

Mac Nally, R. G., Molyneux, J. R., Thomson, P. S., Lake, \& J. Read. (2008). Variation in widths of riparian-zone vegetation of higher-elevation streams and implications for conservation management. Plant Ecology, 198(1), 89-100. http://dx.doi.org/10.1007/s11258-007-9387-5

Marczak, L. B., Sakamaki, T., Turvey, S. L., Deguise, I., Wood, S. L. R., \& Richardson, J. S. (2010). Are forested buffers an effective conservation strategy for riparian fauna? An assessment using meta-analysis. Ecological Applications, 20(1), 126-134. http://dx.doi.org/10.1890/08-2064.1

Mascarúa López, L. E., Harper, K. A., \& Drapeau, P. (2006). Edge influence on forest structure in large forest remnants, cutblock separators, and riparian buffers in managed black spruce forests. Ecoscience, 13(2), 226-233. http://dx.doi.org/10.2980/11195-6860-13-2-226.1

McComb, B. C. (2008). Wildlife habitat management: Concepts and applications in forestry. Boca Raton, FL, USA: CRC Press, Taylor \& Francis Group.

McKendry, K. (2008). An exploration of potential effects of historic dams on the distribution of wetland-dependent species in the Mersey and Medway watersheds of Nova Scotia, Canada. Halifax, Nova Scotia, Canada: M.Sc. thesis, School for Resource and Environmental Studies, Dalhousie University.

Merritt, D. M., Scott, M. L., Poff, N. L., Auble, G. T., \& Lytle, D. A. (2009). Theory, methods and tools for determining environmental flows for riparian vegetation: riparian vegetation-flow response guilds. Freshwater Biology, 54(1), 1-20. http://dx.doi.org/10.1111/j.1365-2427.2009.02206.x

Meyer, J. L., Kaplan, L. A., Newbold, D., Strayer, D. L., Woltemade, C. J., Zedler, J. B., ... Zedler, P. H. (2007a). Where rivers are born: The scientific imperative for defending small streams and wetlands. Retrieved

from http://www.americanrivers.org/assets/pdfs/reports-and-publications/WhereRiversAreBorn1d811.pdf

Meyer, J. L., Strayer, D. L., Wallace, J. B., Eggert, S. L., Helfman, G. S., \& Leonard, N. E. (2007b). The contribution of headwater streams to biodiversity in river networks. Journal of the American Water Resources Association, 43(1), 86-103. http://dx.doi.org/10.1111/j.1752-1688.2007.00008.x.

Mitsch, W. J., \& Gosselink, J. G. (2000). Wetlands (3rd ed). New York, NY, USA: John Wiley. 
Moore, J. W. (2006). Animal ecosystem engineers in streams. Bioscience, 56(3), 237-246. http://dx.doi.org/10.1641/0006-3568(2006)056[0237:AEEIS]2.0.CO;2

Moore, R. D., Spittlehouse, D. L., \& Story, A. (2005). Riparian microclimate and stream temperature response to forest harvesting: A review. Journal of the American Water Resources Association, 41(4), 813-834. ttp://dx.doi.org/10.1111/j.1752-1688.2005.tb04465.x

Muto, E. A., Kreutzweiser, D. P., \& Sibley, P. K. (2009). The influence of riparian vegetation on leaf litter inputs to Boreal Shield streams: implications for partial-harvest logging in riparian reserves. Canadian Journal of Forest Research, 39(5), 917-927. http://dx.doi.org/10.1139/X09-017

Naiman, R. J., Bilby, R. E., \& Bisson, P. A. (2000). Riparian ecology and management in the Pacific coastal rain forest. $\quad$ Bioscience, $50(11)$, 996-1011. http://dx.doi.org/10.1641/0006-3568(2000)050[0996:REAMIT]2.0.CO;2

Naiman, R. J., Bunn, S. E., Nilsson, C., Petts, G. E., Pinay, G., \& Thompson, L. C. (2002). Legitimizing fluvial ecosystems as users of water: An overview. Environmental Management, 30(4), 455-467. http://dx.doi.org/10.1007/s00267-002-2734-3

Naiman, R. J., Décamps, H., \& McClain, M. E. (2005). Riparia: Ecology, conservation, and management of streamside communities. Boston, MA, USA: Elsevier Academic Press.

Naiman, R. J., Décamps, H., \& Pollock, M. (1993). The role of riparian corridors in maintaining regional biodiversity. Ecological Applications, 3(2), 209-212. http://dx.doi.org/10.2307/1941822

Naiman, R. J., \& Dudgeon, D. (2011). Global alteration of freshwaters: influences on human and environmental well-being. Ecological Research, 26(5), 865-873. http://dx.doi.org/10.1007/s11284-010-0693-3

Naiman, R. J., \& Latterell, J. J. (2005). Principles for linking fish habitat to fisheries management and conservation. Journal of Fish Biology, 67, 166-185. http://dx.doi.org/10.1111/j.1095-8649.2005.00921.x

Naiman, R. J., Latterell, J. J., Pettit, N. E., \& Olden, J. D. (2008). Flow variability and the biophysical vitality of $\begin{array}{llll}\text { river systems. Comptes Rendus Geoscience, } & \text { 340(9-10), }\end{array}$ http://dx.doi.org/10.1016/j.crte.2008.01.002

Naiman, R. J., Pinay, G., Johnston, C. A., \& Pastor, J. (1994). Beaver influences on the long-term biogeochemical characteristics of boreal forest drainage networks. Ecology, 75(4), 905-921. http://dx.doi.org/10.2307/1939415

Naiman, R. J., \& Rogers, K. H. (1997). Large animals and system level characteristics in river corridors. Bioscience, 47(8), 521-529. http://dx.doi.org/10.2307/1313120

Neary, D. G., Ice, G. G., \& Jackson, C. R. (2009). Linkages between forest soils and water quality and quantity. Forest Ecology \& Management, 258(10), 2269-2281. http://dx.doi.org/10.1016/j.foreco.2009.05.027

Nova Scotia Museum of Natural History. (1996). The natural history of Nova Scotia, Volume 2 - Theme regions. Retrieved from http://museum.gov.ns.ca/mnh/nature/nhns2/

NRC - National Research Council (U.S.) - Committee on Riparian Zone Functioning and Strategies for Management. (2002). Riparian areas: Functions and strategies for management. Washington, DC, USA: National Academy Press.

NSDNR - Nova Scotia Department of Natural Resources - Forestry Division. (2006). Photo interpretation specifications. Retrieved

from http://www.gov.ns.ca/natr/library/FORESTRY/inventory/Photointerpspecs.pdf

NSDNR - Nova Scotia Department of Natural Resources - Forest Division, GIS Section. (2009a). Forest inventory database. Retrieved September 24, 2009, from http://www.gov.ns.ca/natr/forestry/GIS/forest-inventory.asp

NSDNR - Nova Scotia Department of Natural Resources - Forest Division, GIS Section. (2009b). Restricted land use database. Retrieved September 4, 2009, from http://www.gov.ns.ca/natr/forestry/rlul/download.asp

O'laughlin, J., \& Belt, G. H. (1995). Functional approaches to riparian buffer strip design. Journal of Forestry, 93(2), 29-32.

Olson, D. H., Anderson, P. D., Frissell, C. A., Welsh Jr., H. H., \& Bradford, D. F. (2007). Biodiversity management approaches for stream-riparian areas: Perspectives for Pacific Northwest headwater forests, 
microclimates, and amphibians. Forest Ecology \& Management, 246(1), 81-107. http://dx.doi.org/10.1016/j.foreco.2007.03.053

Olson, D. H., \& Burnett, K. M. (2009). Design and management of linkage areas across headwater drainages to conserve biodiversity in forest ecosystems. Forest Ecology \& Management, 258, S117-S126. http://dx.doi.org/10.1016/j.foreco.2009.04.018

Palik, B. J., Zasada, J. C., \& Hedman, C., W. (2000). Ecological principles for riparian silviculture. In E. S. Verry, J. W. Hornbeck \& C. A. Dolloff (Eds.), Riparian management in forests of the continental Eastern United States (pp. 233-254). Boca Raton, FL, USA: Lewis Publishers.

Paul, M. J., \& Meyer, J. L. (2001). Streams in the urban landscape. Annual Review of Ecology \& Systematics, 32, 333-365. http://dx.doi.org/10.1146/annurev.ecolsys.32.081501.114040

Phillips, M. J., Swift, L. W., \& Blinn, C. R. (2000). Best management practices for riparian areas. In E. S. Verry, J. W. Hornbeck \& C. A. Dolloff (Eds.), Riparian management in forests of the continental Eastern United States (pp. 273-286). Boca Raton, FL, USA: Lewis Publishers.

Potvin, F., \& Bertrand, N. (2004). Leaving forest strips in large clearcut landscapes of boreal forest: A management scenario suitable for wildlife? Forestry Chronicle, 80(1), 44-53.

Pringle, C. M. (2001). Hydrologic connectivity and the management of biological reserves: A global perspective. $\begin{array}{lll}\text { Ecological Applications, } & \text { 981-998. }\end{array}$ http://dx.doi.org/10.1890/1051-0761(2001)011[0981:HCATMO]2.0.CO;2

Pusey, B. J., \& Arthington, A. H. (2003). Importance of the riparian zone to the conservation and management of freshwater fish: a review. Marine \& Freshwater Research, 54(1), 1-16. http://dx.doi.org/10.1071/MF02041

Quinby, P. A., Willott, S., \& Lee, T. (2000). Determining the average width of the riparian zone in the Cassels-Rabbit lakes area of Temagami, Ontario using understory indicator species. Retrieved from http://www.ancientforest.org/rr25.html

Rabeni, C. F., \& Smale, M. A. (1995). Effects of siltation on stream fishes and the potential mitigating role of the buffering riparian zone. Hydrobiologia, 303(1-3), 211-219. http://dx.doi.org/10.1007/BF00034058

Rambo, T. R., \& North, M. P. (2008). Spatial and temporal variability of canopy microclimate in a Sierra Nevada riparian forest. Northwest Science, 82(4), 259-268. http://dx.doi.org/10.3955/0029-344X-82.4.259

Reid, L. M., \& Hilton, S. (1998). Buffering the buffer. In R.R. Ziemer (Ed,). Conference on coastal watersheds: The Caspar Creek story, Ukiah, CA, USA, 6 May 1998. USDA Forest Service General Technical Report PSW-GTR-168 (pp. 71-80). http://www.fs.fed.us/psw/publications/documents/gtr-168/08reid.pdf

Richardson, J. S. (2004). Meeting the conflicting objectives of stream conservation and land use through riparian management: Another balancing act. In G.J. Scrimgeour, G. Eisler, B. McCulloch, U. Silins \& M. Monita (Eds). Forest land-fish conference II - ecosystem stewardship through collaboration, Edmonton, Alberta, Canada, April 26-28 $2004 \quad$ (pp. 1-6). Retrieved from http://www.for.gov.bc.ca/hfd/library/ffip/Richardson_JS2004.pdf

Richardson, J. S., \& Danehy, R. J. (2007). A synthesis of the ecology of headwater streams and their riparian zones in temperate forests. Forest Science, 53(2), 131-147.

Richardson, J. S., Naiman, R. J., \& Bisson, P. A. (2012). How did fixed-width buffers become standard practice for protecting freshwaters and their riparian areas from forest harvest practices? Freshwater Science, 31(1), 232-238. http://dx.doi.org/10.1899/11-031.1

Richardson, J. S., Naiman, R. J., Swanson, F. J., \& Hibbs, D. E. (2005). Riparian communities associated with Pacific Northwest headwater streams: Assemblages, processes, and uniqueness. Journal of the American Water Resources Association, 41(4), 935-947. http://dx.doi.org/10.1111/j.1752-1688.2005.tb03778.x

Richardson, J. S., Zhang, Y., \& Marczak, L. B. (2010). Resource subsidies across the land-freshwater interface and responses in recipient communities. River Research and Applications, 26(1), 55-66. http://dx.doi.org/10.1002/rra.1283

Roberge, J. M., \& Angelstam, P. (2004). Usefulness of the umbrella species concept as a conservation tool. Conservation Biology, 18(1), 76-85. http://dx.doi.org/10.1111/j.1523-1739.2004.00450.x 
Rodewald, A. D., \& Bakermans, M. H. (2006). What is the appropriate paradigm for riparian forest conservation? Biological Conservation, 128(2), 193-200. http://dx.doi.org/10.1016/j.biocon.2005.09.041

Rosell, F., Bozser, O., Collen, P., \& Parker, H. (2005). Ecological impact of beavers Castor fiber and Castor canadensis and their ability to modify ecosystems. Mammal Review, 35(3-4), 248-276. http://dx.doi.org/10.1111/j.1365-2907.2005.00067.x

Ruel, J. C., Pin, D., \& Cooper, K. (2001). Windthrow in riparian buffer strips: Effect of wind exposure, thinning and strip width. Forest Ecology \& Management, 143(1-3), 105-113. http://dx.doi.org/10.1016/S0378-1127(00)00510-7

Semlitsch, R. D., \& Bodie, J. R. (1998). Are small, isolated wetlands expendable? Conservation Biology, 12(5), 1129-1133. http://dx.doi.org/10.1046/j.1523-1739.1998.98166.x

Semlitsch, R. D., \& Bodie, J. R. (2003). Biological criteria for buffer zones around wetlands and riparian habitats for amphibians and reptiles. Conservation Biology, 17(5), 1219-1228. http://dx.doi.org/10.1046/j.1523-1739.2003.02177.x

Shandas, V., \& Alberti, M. (2009). Exploring the role of vegetation fragmentation on aquatic conditions: Linking upland with riparian areas in Puget Sound lowland streams. Landscape \& Urban Planning, 90(1-2), 66-75. http://dx.doi.org/10.1016/j.landurbplan.2008.10.016

Shirley, S. M., \& Smith, J. N. M. (2005). Bird community structure across riparian buffer strips of varying width in a coastal temperate forest. Biological Conservation, 125(4), 475-489. http://dx.doi.org/10.1016/j.biocon.2005.04.011

SNS\&MR - Service Nova Scotia and Municipal Relations. (2008). Hydrography - Nova Scotia topographic database (NSTDB) resource series, version 3. Retrieved April 3, 2009, from http://www.nsgc.gov.ns.ca/mappingspecs/Specifications/Compilation/Resource_Version3/default.htm

SNS\&MR - Service Nova Scotia and Municipal Relations - GeoServices section. (2009a). Nova Scotia Geomatics Centre data locator - 1:10 000 database. Retrieved September 15, 2009, from http://www.gov.ns.ca/geonova/home/products/softpage/data_locator.asp

SNS\&MR - Service Nova Scotia and Municipal Relations. (2009b). Nova Scotia's Geographic Information Standards - Chapter 4: Data quality and accuracy. Retrieved April 3, 2009, from http://www.gov.ns.ca/snsmr/land/standards/post/manual/ch4_toc.asp

Southwest Nova Biosphere Reserve Association. (2001). Biosphere reserve nomination for Southwest Nova Biosphere Reserve, UNESCO, Paris, France. Retrieved July 6, 2009, from http://www.snbra.ca/download/snbr_nom_doc.pdf

Spackman, S. C., \& Hughes, J. W. (1995). Assessment of minimum stream corridor width for biological conservation: Species richness and distribution along mid-order streams in Vermont, USA. Biological Conservation, 71(3), 325-332. http://dx.doi.org/10.1016/0006-3207(94)00055-U

Stanford, J. A., Frissell, C. A., \& Coutant, C. C. (2006). The status of freshwater habitats. In R. N. Williams (Ed.), Return to the river: Restoring salmon to the Columbia River (pp. 173-248). Boston, MA, USA: Elsevier Academic Press. http://dx.doi.org/10.1016/B978-012088414-8/50008-4

Stein, E. D., \& Ambrose, R. F. (2001). Landscape-scale analysis and management of cumulative impacts to riparian ecosystems: Past, present, and future. Journal of the American Water Resources Association, 37(6), 1597-1614. http://dx.doi.org/10.1111/j.1752-1688.2001.tb03663.x

Stoffyn-Egli, P., \& Willison, J. H. M. (2011). Including wildlife habitat in the definition of riparian areas: The beaver (Castor canadensis) as an umbrella species for riparian obligate animals. Environmental Reviews, 19, 479-493. http://dx.doi.org/10.1139/A11-019

UNESCO. (2000). Solving the puzzle: The ecosystem approach and biosphere reserves. Retrieved from http://unesdoc.unesco.org/images/0011/001197/119790eb.pdf

Urban, M. C., Skelly, D. K., Burchsted, D., Price, W., \& Lowry, S. (2006). Stream communities across a $\begin{array}{lllll}\text { rural-urban landscape gradient. Diversity } & \text { Distributions, } & \text { 12(4), } & \text { 337-350. }\end{array}$ http://dx.doi.org/10.1111/j.1366-9516.2005.00226.x

USDA: United States Department of Agriculture - Forest Service. (2008). Stream Systems Technology Center

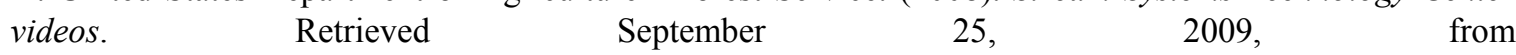
http://www.stream.fs.fed.us/publications/videos.html\#eastandwest 
Vanni, M. J. (2002). Nutrient cycling by animals in freshwater ecosystems. Annual Review of Ecology and Systematics, 33, 341-370. http://dx.doi.org/10.1146/annurev.ecolysis.33.010802.150519

Verry, E. S., Dolloff, C. A., \& Manning, M. E. (2004). Riparian ecotone: A functional definition and delineation for resource assessment. Water, Air, \& Soil Pollution, 4(1), 67-94. http://dx.doi.org/10.1023/B:WAFO.0000012825.77300.08

Vesely, D. G., \& McComb, W. C. (2002). Salamander abundance and amphibian species richness in riparian buffer strips in the Oregon Coast Range. Forest Science, 48(2), 291-297.

Weller, D. E., Jordan, T. E., \& Correll, D. L. (1998). Heuristic models for material discharge from landscapes $\begin{array}{lllll}\text { with riparian } & \text { buffers. Ecological }\end{array}$ http://dx.doi.org/10.1890/1051-0761(1998)008[1156:HMFMDF]2.0.CO;2

Wenger, S. (1999). A review of the scientific literature on riparian buffer width, extent and vegetation. Retrieved from http://www.rivercenter.uga.edu/service/tools/buffers/buffer_lit_review.pdf

Wheeler, A. P., Angermeier, P. L., \& Rosenberger, A. E. (2005). Impacts of new highways and subsequent landscape urbanization on stream habitat and biota. Reviews in Fisheries Science, 13(3), 141-164. http://dx.doi.org/10.1080/10641260590964449

Wipfli, M. S., Richardson, J. S., \& Naiman, R. J. (2007). Ecological linkages between headwaters and downstream ecosystems: Transport of organic matter, invertebrates, and wood down headwater channels. Journal of the American Water Resources Association, 43(1), 72-85. http://dx.doi.org/10.1111/j.1752-1688.2007.00007.x

Young, K. A. (2000). Riparian zone management in the Pacific Northwest: Who's cutting what? Environmental Management, 26(2), 131-144. http://dx.doi.org/10.1007/s002670010076

Zhang, X., Liu, X., Zhang, M., Dahlgren, R. A., \& Eitzel, M. (2010). A review of vegetated buffers and a meta-analysis of their mitigation efficacy in reducing nonpoint source pollution. Journal of environmental quality, 39(1), 76-84. http://dx.doi.org/10.2134/jeq2009.0496

Zhang, Y., Richardson, J. S., \& Pinto, X. (2009). Catchment-scale effects of forestry practices on benthic invertebrate communities in Pacific coastal streams. Journal of Applied Ecology, 46(6), 1292-1303. http://dx.doi.org/10.1111/j.1365-2664.2009.01718.x

\section{Copyrights}

Copyright for this article is retained by the author(s), with first publication rights granted to the journal.

This is an open-access article distributed under the terms and conditions of the Creative Commons Attribution license (http://creativecommons.org/licenses/by/3.0/). 